\title{
The Use of Activity, Classroom Discussion, and Exercise (ACE) Teaching Cycle for Improving Students' Engagement in Learning Elementary Linear Algebra
}

\author{
Hendra Syarifuddin ${ }^{1 *}$, Bill Atweh ${ }^{2}$ \\ ${ }^{1}$ Universitas Negeri Padang, INDONESIA \\ 2 Curtin University, AUSTRALIA \\ *Corresponding author: hendrasyarifuddin484@gmail.com
}

Received: 2 Sep. 2021 Accepted: 17 Oct. 2021

Citation: Syarifuddin, H., \& Atweh, B. (2022). The Use of Activity, Classroom Discussion, and Exercise (ACE) Teaching Cycle for Improving Students' Engagement in Learning Elementary Linear Algebra. European Journal of Science and Mathematics Education, 10(1), 104-138. https://doi.org/10.30935/scimath/11405

\begin{abstract}
:
The main focus of the study was to identify the the effects of the ACE teaching cycle approach on students' engagement in learning of Elementary Linear Algebra. The Elementary Linear Algebra course was delivered at the Mathematics Education Study Program of State University of Padang, Indonesia. An action research methodology was adopted for the study and the constructivist theory was used as a theoretical framework. This study used mixed methods to collect, describe, and interpret the data. The data were collected through focus group discussion, classroom observations, and questionnaire. The participants in this study consisted of 37 students enrolled in the Elementary Linear Algebra course during the January-June 2011 semester. The ACE teaching cycle approach that was implemented in this study consisted of three steps. The first step in this cycle was the concept maps activity. This activity encouraged students to prepare for the topics that would be discussed in the class. The next step was classroom discussion which provided a social context in which the students could work together to solve mathematics problems. Finally, exercises were assigned as homework. In this part, students practised solving mathematics problems and wrote reflective journal. Students' involvement in the ACE teaching cycle approach in the Elementary Linear Algebra course improved their engagement in mathematics learning in the three domains of cognitive engagement, affective engagement and behavioural engagement.

Keywords: classroom discussion, student, engagement, learning, mathematics
\end{abstract}

\section{INTRODUCTION}

The purpose of this research was to improve teaching and learning mathematics in higher education in Indonesia. One of the issues that have been encountered in education in Indonesia are the low level of students' engagement in learning mathematics (Açıkgül \& Şad, 2020, 2021; Casinillo et al., 2020; FuentesCabrera et al., 2020; Mainali, 2021; Mazana et al., 2019; Mulenga \& Marbán, 2020; Rohaizati, 2020). As a mathematics lecturer at State University of Padang, author also found that this issue have become major problems of my teaching practice. Students' engagement in the teaching and learning process is a significant goal in education (Elmore, 1990). Despite its importance, student disengagement in learning is still a problem in education. Disengagement leads to reducing the variety of knowledge and information that can be achieved by students in their learning. In addition, students who are disengaged in learning limit their capacity to understand their learning experiences (Attard, 2011; Baek, 2019; Cho et al., 2021; Hava et al., 2020; Peker \& Ataöv, 2020; Selvanathan et al., 2020; Tsybulsky, 2020).

To improve my teaching and learning practice and to overcome these two issues I chose to implement the Activities, Classroom-discussion and Exercises (ACE) teaching cycle approach (Arnawa, 2006; 
Asiala et al., 1997; Borji \& Voskoglou, 2017; Dubinsky, 1995). The ACE teaching cycle is an instructional model that is based on constructivist theory. This study investigated the impact of the use of the ACE approach on students' engagement in learning elementary linear algebra. The ACE teaching cycle is expected to improve students' engagement.

This study was conducted in the Mathematics Education Study Program of the State University of Padang in Semester January - June of the academic year 2010/2011. State University of Padang is a public university which was established in 1954. It ranks as one of the two biggest universities in West Sumatera province, Indonesia. It provides undergraduate courses across seven faculties. State University of Padang is one of the higher education institutions in Indonesia that prepares teachers for schools.

\section{LITERATURE REVIEW}

The teacher training college is the place where pre-service teachers can get knowledge and skills that prepare them to enter the working world. The knowledge and skills that are acquired by students must be appropriate for the needs of their career in teaching. The knowledge and skills that are acquired by prospective mathematics teachers are not only the content knowledge and skills about mathematics but also the pedagogical content knowledge necessary for them to be capable mathematics teachers (Aldon \& Tragalová, 2019; Livy \& Vale, 2011; Potgieter, 2020; Sacristán, 2020; Tabach \& Trgalová, 2018, 2019, 2020). Pedagogical content knowledge is the knowledge that relates to the ways the teacher represents and formulates their knowledge when teaching (Chan \& Hume, 2019; Kind \& Chan, 2019; Neumann et al., 2019; Özgür, 2020; Schmid et al., 2020; Tanak, 2020). Mathematical content knowledge and pedagogical content knowledge are two important dimensions that proficient mathematics teachers require (Askew et al., 2019; Charalambous et al., 2020; Copur-Gencturk et al., 2021; Daniel, 2017; Livy \& Vale, 2011; Livy et al. 2019; Lo, 2020; Ma, 1999; Norton, 2019). The specific subject in which this research was carried out targets the development of mathematics content knowledge of prospective teachers.

According to Taplin (1998), it is often difficult to equip students with the necessary mathematical knowledge because most students enter college with inadequate mathematics skills. As a result, these students experience difficulty in understanding the mathematics concepts because most concepts in mathematics relate to abstract ideas that are related to each other. Students will face difficulties in studying mathematics if they have lost the link between concepts. According Brijlall and Maharaj (2009), many students perform poorly in mathematics because they are unable to adequately handle information given in symbolic form which represent objects, for example mathematical expressions, equations and functions. Besides that problem, according to Maharaj (2011) a high percentage of students have a static view about mathematics; students with such a view will experience difficulties in learning mathematics in depth and will find it difficult to engage in teaching and learning processes. So, these problems are related to students' mathematics learning and students' engagement in the classroom.

Another problem of teaching mathematics to prospective mathematics teachers is the teaching and learning process in some teachers' colleges still involves the teacher-centred approach. This teachercentred teaching and learning approach does not give the optimal provision for students to be able to be proficient teachers. In the teacher-centred classroom, students' display high dependence on the lecturer to acquire knowledge and skills while their opportunity to interact and socialize between them is very limited. The prospective teachers need the opportunity to develop as independent learners. This ability will help them to grow successfully in their careers as teachers. In college, students must also develop their abilities in socializing, discussing, and sharing of ideas between themselves (Dikici, 2006; Pedro \& Brunheira, 2001). 
State University of Padang is the largest university in West Sumatra, Indonesia that prepares teachers for primary and secondary schools. Based on author experience as a staff member of State University of Padang, I can say that most of the teaching and learning processes at the university are still conducted traditionally where lecturers become the main actors in the classroom - also known as teacher-centred teacher. The teaching and learning process follows the same pattern for each session. Generally, mathematics lectures follow four teaching steps when they teach mathematics: 1) explaining the topic, 2 ) giving examples, 3) asking students to do exercises, and 4) giving homework. According to Nesmith (2008) the lecturer's role in traditional mathematics classroom is to (1) provide all topics which are planned, demonstrate procedures, (2) reiterate steps in answering students' questions, (3) provide sufficient opportunities for students to be drilled in the procedures, and (4) offer specific corrective support. These roles identify the lecturer as a central figure in the teaching and learning process and portray students as receivers of knowledge in the classroom. The traditional curriculum is based on the transmission of knowledge from lecturer to students and does not encourage students to be actively involved in the classroom (Dinh, 2019; Kent et al., 1997; LaMotte, 2018; Shrivastava \& Shrivastava, 2020). As a result, students are unable to acquire a variety of experiences in the learning process and their learning outcomes might be restricted to knowledge of content and related skills.

The main features of the traditional curriculum are lecturer domination over organisation and action, teacher selection and transfer of knowledge (Al Ansari et al., 2021; Cano et al., 2018; Cattaneo et al., 2019; De Oliveira et al., 2018; Exley, 2008; Nguyen et al., 2018; Scott \& Husain, 2021). Regarding organisation and action, the lecturer is the central figure who organises the contents of the course and the strategies that will be implemented in the classroom. The next feature of lecturer selection requires the lecturer as the person who decides what topics are to be presented and what strategy will be used to present the topics. As for transfer of knowledge, the lecturer tends to explain her or his knowledge in the classroom. $\mathrm{S} /$ he is more concerned with the completeness of giving materials and focuses on how far students understand the contents of the course. In such a curriculum, most of the time in the classroom is allocated to support direct transfer of knowledge from the lecturer to students. Lecturer domination in the classroom does not result in the maximum benefit of students' engagement and learning in the classroom.

In the teaching and learning process using the traditional curriculum, students are passive while the lecturer dominates class activities. Students are not provided with sufficient opportunities to learn through various sources and various activities, thus limiting their engagement and their learning. In term of students' engagement, students do not have sufficient opportunities to be involved in the teaching and learning process. Students lack opportunities to deepen their understanding, and are provided with limited opportunities to develop their self-learning ability and to communicate with each other in the class. Classrooms that are dominated by the lecturer also have a negative impact on students' affective engagement like interest and achievement orientation, and behavioural engagement like attentiveness and diligence (Kong et al., 2003). In terms of students' learning, students do not have; sufficient opportunities to improve their understanding of concepts and procedures as well as to improve their ability in problem solving and communication (NCTM, 2000).

Teaching and learning mathematics should enable students to acquire a variety of experiences through various sources and activities so that students have more opportunities to increase their engagement in the teaching and learning process. Evidence shows that the focus of the teaching and learning process must be the students as in student-centred learning instruction. Hence, the lecturer must function as a facilitator and her or his main role is to encourage students to be actively involved in their learning so that they are able to construct understanding through their own active engagement and their own previous knowledge. Therefore, the traditional mathematics curriculum model needs to be changed in order to improve students' learning of mathematics and to enhance their engagement. To accommodate this change, one approach that can be adopted by the lecturer is informed by constructivism. 
Constructivism is a theory about learning (Ganapathy et al., 2017; Jitka et al., 2018; King, 2002). The main concept of constructivism is that learning is an active process of creating knowledge rather than acquiring or transferring knowledge. Constructivism is all about inquiry, exploration, autonomy, and personal expressions of knowledge and creativity. The following principles provide a general framework of constructivism and its relevance for instruction: (1) Learners bring unique prior knowledge and beliefs to a learning situation. Each student in a classroom has different background and different ability to learn the same topic. The lecturer should be aware of these differences. (2) Knowledge is constructed uniquely and individually, in multiple ways, through a variety of tools, resources, and contexts. The lecturer should familiarise students with various teaching and learning strategies. (3) Learning is both an active and reflective process. (4) Learning is developmental. We make sense of our world by assimilating, accommodating, or rejecting new information. (5) Social interaction introduces multiple perspectives in learning. (6) Learning is internally controlled and mediated by the learner (Technology Assistance Program, 1998).

The Constructivist theory can be summarized in a single statement: Knowledge is constructed in the mind of the learner (Bodner, 1986; Bodner \& Elmas, 2020; Pazicni \& Flynn, 2019; Salame et al., 2020). This theory suggests that, to the extent that the individuals' understandings are built from their unique web of prior concepts and their current subjective experiences. Teachers or lecturers should not attempt to transfer their knowledge into their students' minds. The learner must actively engage in problem situations in order to build understandings which are an extension of, and later become an integral part of, his or her cognitive web (Schifter \& Simon, 1992).

Classroom activities are an important aspect of the lecturers' task in the teaching and learning process based on the constructivist approach where the lecturer acts as a facilitator (Akilli \& Genç, 2017; Copley, 1992; Denton et al., 2018; Janna et al., 2019; Werner et al., 2018). The lecturer plans the scenario on how the teaching and learning will be conducted. There is no fixed pattern that should be followed by a lecturer for a constructivist classroom, and teaching practices based on constructivism are varied and flexible. However, there are substantial similarities across constructivist classrooms, namely students are actively engaged, are conscious of their own learning and are able to work collaboratively to solve problems that have real meaning for them. In short, in a constructivism classroom, learning is something a student does - not something that is done to the student (Agustini, 2019; Masaviru, 2020; Sulistyowati, 2019; Technology Assistance Program, 1998).

The traditional teacher-centred model needs to be changed in order to improve both the quality of the teaching practice and student learning of mathematics. The focus of the teaching and learning process must be the students in student-centred learning. To accommodate this model, one approach for the teaching and learning process that can be adopted by the lecturer is informed by constructivism. According to Driscoll (2000), and Fosnot (1996) the constructivist approach in the teaching and learning process facilitates student thinking, active learning, and highlights students' ability in communication, reasoning and conceptual understanding as presented in the National Council of Teachers of Mathematics' Principles and Standards for School Mathematics (NCTM, 2000).

One of the teaching models that can be used to implement the instructional treatments based on constructivism is called the ACE (Activity, Classroom Discussion, Exercises) teaching cycle (Dubinsky, 2001). This model was first introduced by Dubinsky (1995) to help students' learning of mathematics through the use of computer programming. In this design, Dubinsky broke up the course into sections, each of which was conducted in one week. During the week, the class met on some days in the computer laboratory and on other days in a normal classroom in which there were no computers. Homework was done outside of classroom. Dubinsky (1995) implemented the three components of the model as follows:

Activities: the class met in a computer laboratory where students worked in teams on computer tasks. The lab assignments were generally too long to finish during the scheduled lab time and students were expected to come to the lab when it was open or work on their personal computers, or use other labs to 
complete the assignment (Dubinsky, 1995). This activity gave opportunity for students to explore their previous knowledge which related to the topics they were studying.

Classroom discussion: the class met in a classroom where students worked in groups to perform paper and pencil tasks based on the computer activities in the lab. The instructor led inter-group discussions designed to give students an opportunity to reflect on the tasks they had been working on. On occasion, the instructor would provide definitions, explanations, and an overview to tie together what the students had been thinking about (Dubinsky, 1995). Through the discussion in the classroom students had opportunities to share their ideas so that they would have better understanding of the concepts.

Exercises: relatively traditional exercises were assigned for students to work on in teams. These were expected to be as homework that was in addition to the lab assignment. The purpose of the exercise was for students to reinforce the ideas they had constructed, to use the mathematics they had learned and, on occasion, to begin thinking about the content that will be studied later (Dubinsky, 1995).

Asiala and his colleagues implemented the ACE teaching cycle in a Calculus course at Midwestern University in USA. They particularly wanted to see the effect of the strategy on students' graphical understanding of a function and its derivative. This was a comparative study. The researchers adopted the stages that were proposed by Dubinsky (1995). Activities: students were given the task that related to the topics which would be discussed in the class. They completed the task using ISETL (Interactive Set Language) mathematics programming software. Classroom discussion: students held discussions in the classroom to solve the issues that they faced in learning the topics. Exercises: this stage was intended to help students reinforce the knowledge they had constructed (Asiala, Cottrill, et al., 1997). In doing their research, they compared students' performance in the experimental class with students' performance in the control class that was taught traditionally (the control group). Students from the two groups were interviewed about their understanding on the derivative of a function at a point graphically. The result of this study was that students who followed the course that was based on ACE teaching cycle approach had more success in developing a graphical understanding of a function and its derivative than students in the control group. The ACE teaching cycle approach was reasonably effective in helping students develop a relatively strong process conception of function and a graphical understanding of the derivative (Asiala, Cottrill, et al., 1997).

Trigueros et al. (2007) used the ACE teaching cycle as an approach in their research on a Linear Algebra course during one semester at an undergraduate institution in Mexico. The strategy that they used to implement the ACE teaching cycle was almost the same as the strategy that was used by Asiala and his colleagues above. In this study, Trigueros and his colleagues proposed the CAS (Computer Algebra System) Maple mathematics software that was used by students to complete their task before class. In their research, they did interview students twice (at the beginning and at the end of the study) to collect data about students' ability in mathematics. In the first interview, the researchers found that the students could be divided into two groups according to their responses to the questions: those who displayed good background knowledge from elementary algebra courses, and those who did not possess such background knowledge. The results of the second interview confirmed that the use of the approach was effective only with students who had good background of elementary algebra. Good understanding of elementary algebra seems to be really important for students to learn the concepts related to systems of equations in the linear algebra course (Trigueros et al., 2007).

Arnawa (2006) had also conducted research using the ACE teaching cycle as a strategy in his teaching practice at Andalas University in Indonesia. The main approach that he used to implement the ACE teaching cycle was almost the same as the strategy that was used by Asiala et al. (1997). He also used the ISETL mathematics programming software for activities in the computer laboratory and cooperative group learning for discussion in the classroom. His research aim was to investigate the differences between students who attended the class using the ACE teaching cycle approach (experimental group) and students who attended the class using a traditional approach (control group) in their ability to prove 
Table 1. Mean value of attitude scales on experimental group and control group of Arnawa's Study (N $=180$ )

\begin{tabular}{lcccccccccc}
\hline \multirow{2}{*}{ Group } & \multicolumn{1}{c}{} & \multicolumn{4}{c}{ Means of attitude scale } & \multicolumn{3}{c}{ Average } \\
\cline { 2 - 7 } & $\mathrm{A}$ & $\mathrm{B}$ & $\mathrm{C}$ & $\mathrm{D}$ & $\mathrm{E}$ & $\mathrm{F}$ & $\mathrm{G}$ & $\mathrm{H}$ & Mean \\
\hline Experiment & 3.98 & 3.64 & 3.73 & 3.76 & 3.81 & 3.47 & 4.49 & 3.72 & 3.83 \\
Traditional & 3.52 & 3.46 & 3.35 & 3.49 & 3.31 & 3.32 & 3.96 & 3.22 & 3.41 \\
\hline
\end{tabular}

Source: Arnawa (2006)

theorems and students' attitude in learning abstract algebra. The researcher obtained data from a mathematics test and an attitudes questionnaire at the end of his study to investigate the differences, if any. The result of his research was that the students who attended the class based on the ACE teaching cycle approach were able to prove theorems significantly better than students from the traditional class. Meanwhile, his study on students' attitudes revealed that students who attended the class using the ACE teaching cycle approach had more positive attitudes towards the teaching and learning process of abstract algebra than students who attended the traditional class (Arnawa, 2006). In his study, Arnawa used 8 aspects (scales) to measure students attitudes namely, confidence (A), anxiety (B), attitude on the usefulness of abstract algebra (C), attitude for success (D), encouragement for success (E), perception on lecturer support $(F)$, perception on learning in small groups $(G)$, and perceptions about the lecturer's and students' role in the teaching and learning process $(\mathrm{H})$. Table 1 presents the result of mean value of the eight scales of the attitude questionnaire on the experimental group and control group.

In implementing the ACE teaching cycle, researchers of the three studies used computer technology in teaching and learning mathematics. Students were encouraged to learn the contents to be discussed in the classroom using mathematics software. Through the use of the software, students were expected to be able to construct their understanding.

The studies focused on using technology in learning of content. They required a computer laboratory, the availability of mathematics software, and skill in using computers. If any of these conditions were not met, then the implementation of the ACE teaching cycle as applied by the above three studies would not have been successful. We need an alternative so that the application of the ACE teaching cycle does not depend on computer technology.

In this study, the scenario that author used to implement the ACE teaching cycle in an Elementary Linear Algebra course involved the following three stages: (1) Activity: Asiala, et al. (1997), Trigueros et al. (2007), and Arnawa (2006) used mathematics programming language like ISETL and CAS Maple as students' activities before class. In this study, author used concept maps as students' activity before class. Students worked together in small groups (two or three members) to create concept maps. The main focus of this activity was to encourage students to explore their previous knowledge in order to build new desired mental constructions (Asiala, Cottrill, et al., 1997; Dubinsky, 2001). (2) Classroom discussion: students used cooperative group learning. They were grouped into permanent teams consisting of four, five, or six members each. In the group, they discussed solving of mathematics problems. This provided a social context in which the students could work together to solve mathematics problems. This classroom discussion was no different from what had been done by Asiala, Trigueros, and Arnawa. (3) Exercises: students were given homework to be completed outside of class. There were two kinds of homework which they had to complete traditional exercises and a reflective journal. This was different from the three previous studies above that used traditional exercises as homework but did not require students to complete reflective journals. In this study, students completed traditional exercises in small groups (same groups as when they created the concept maps), while to complete the reflective journal students wrote individually. The use of the ACE teaching cycle as an approach in this study is expected to produce a positive effect on students' engagement in learning. 
According to Elmore (1990) student engagement in the teaching and learning process is a significant goal for education. Student engagement in learning leads to achievement and influences to students' cognitive and social development (Finn, 1993; Newmann, 1992). Students who are engaged with the learning process are more likely to be involved in learning seriously, to get meaningful experience, and to pursue higher education (Marks, 2000). However, student disengagement in learning is still a problem in education. Disengagement leads to reducing the variety of knowledge and information that can be absorbed by students in learning. In addition, students who are disengaged in learning limit their capacity to understand learning experiences (Attard, 2011).

Newmann and Lamborn (1992) defined engagement as students' psychological investment in and effort directed towards learning, understanding, or mastering the knowledge, skills, or crafts that academic work is intended to promote. D'mello (2008) described engagement as student's willingness, need, desire and compulsion to participate in, and be successful in, the learning process. It is an important issue in teaching because it affects how much students learn on a daily basis. The engagement depends greatly on students' interest and the teacher's ability to create an environment that invites students to learn (D'mello, 2008; Tomlinson, 2002).

Student engagement is generally recognized as one of the better predictors of learning (Carini et al., 2006; Caulfield, 2010). So, creating the teaching strategy that improve students engagement will lead to increased student learning, which is the main goal for both students and teachers. The challenge for a teacher is to create a setting and activities that students find engaging and that are able to advance their proficiency in abilities that they find useful. Such instruction helps learners to find the curriculum comprehensible and stimulating, inclusive and promotes a supportive classroom (Cole, 1996).

Tomlinson (2002) expresses five important criteria for a student's engagement in the classroom: (1) Purpose - students need to know what they do at school, realise the significance in it and know that the work they do makes a difference to the world. Knowing the importance of the topics that they learn would encourage them to become actively involved in the teaching and learning process. (2) Contribution - each student needs to feel that they can make a difference. They want to bring something unique and valuable for other friends in the class. The opportunity to be able to contribute in the classroom will encourage them to stay engaged in the teaching and learning process. (3) Affirmation is important for students to know that they are accepted, safe, and understood. This condition will encourage students to feel comfortable and give them the opportunity to learn better in the classroom. (4) Power - students need to believe that the knowledge which they have acquired is useful and will assist them on their journey beyond the classroom. The belief that the topics which they are learning will be useful in their lives will encourage them to be more diligent in learning. (5) Challenge - the tasks need to stretch the students and they need to know when they work hard they generally succeed, that they are accountable for their own growth and that they are able to contribute to the growth of others. The awareness that they have to develop will encourage them to be more involved in the learning activities.

In this study, the degree of student engagement in the classroom would be investigated through three domains namely, cognitive engagement, affective engagement and behavioural engagement (Caulfield, 2010; Chapman, 2003).

Cognitive engagement is closely related to academic involvement or approaches to learning involve the ideas of investment, recognition of the value of learning and a willingness to go beyond the minimum requirement (Attard, 2011; Fredricks et al. , 2004). According to Biggs (1978), and Kong et al. (2003), there are three approaches to learning, namely; surface strategy (closely associated with lower levels of learning outcomes - memorisation, practising, handling tests), deep strategy (closely related to higher levels of learning outcomes - understanding the question, summarising what is learnt, connecting knowledge with the old ways of learning), and reliance (relying on teachers) Behavioural engagement is closely related to student participation in the classroom. Active participation in the classroom is 
demonstrated by compliance with classroom procedures, taking initiative in the group and classroom, becoming involved in classroom activities, asking questions, regularly attending class, and comprehensively completing assignments (Chapman, 2003; Skinner \& Belmont, 1993).

Affective engagement is closely related to students' reactions to the learning environment (school, teachers, peers, and academic curriculum) that influence willingness to become involved in school activities (Attard, 2011; Chapman, 2003). According to Miserandino (1996), and Kong et al. (2003) students' affective engagement can be seen through four dimensions namely, interest, achievement orientation, anxiety and frustration.

In terms of engagement with mathematics, engagement occurs when learners are procedurally engaged in the classroom, actively learning mathematics, participating in all tasks, and hold the view that studying mathematics is useful, valuable, and worthwhile both inside and outside of the classroom (Attard, 2011). The above explanation revealed that the engagement associated with students' involvement in the mathematics learning process is dependent on behavioural, affective, and cognitive aspects of learning.

\section{RESEARCH DESIGN AND METHODS}

In this research, we used an action research methodology. Action research is a systematic investigation conducted by teacher researchers to gather information about how they teach and how well their students learn (Creswell, 2008; Mills, 2007). According to Atweh (2004) through action research teachers/lecturers have an opportunity to improve their practice and to develop an understanding of their practice that will enable them to develop professionally. The action research solves a practical and local problem, such as a classroom issue faced by an educator (Creswell, 2008). McMillan (1992) stated that the aim of action research was to solve a specific classroom problem or to make a decision at a local site in order to improve teaching and learning practice immediately within one or more classrooms. Through action research, teachers or lecturers have the opportunity to improve their teaching practice by studying problems or issues they face. They reflect on these issues, collect and analyse data, and implement changes based on their findings and experiences (Creswell, 2008).

Kemmis and McTaggart (1988) have suggested that action research engages teacher researchers in a four-step process which is called the action research spiral, with its components of planning, acting, observing, reflecting and creating a revised plan. In the planning step, a plan of action is developed to solve a problem which has been identified in order to improve the quality of the teaching and learning practice. In the acting step, the plan is implemented in the teaching and learning activity over a period of time. In the observing step, the effects of the action are observed to ascertain its effectiveness. In the reflecting and creating a revised plan step, the effects of the implementation of action are evaluated to form the basis for the next cycles of research.

In this study, author had planning to improve my teaching practice on Elementary Linear Algebra course at Padang State University by using the ACE teaching cycle approach. author implemented the approach for one semester (January - June 2011). One cycle of action research (planning, acting, observing, reflecting and creating a revised plan) was conducted during each week. Planning - as a lecturer-researcher author had a plan to be implemented every week. This plan was related to the teaching and learning strategy that author would be using in the class. Acting - author tried to implement the plan that author had created in the classroom. Observing - author observed the effects of the use of the plan during that week on the teaching and learning process and students' engagement in learning. Reflecting and creating a revised plan - author did a reflection based on author observations during that week. The results of author reflection would be useful for me to revise the plan and to devise new plan to be implemented the following week.

This study used a mixed methods approach to collect, describe, and interpret the data. According to Creswell (2010), the use of mixed methods in a single study has several advantages. Mixed methods 
research offers strengths that balance the limitations of both quantitative and qualitative research. The combination of the two approaches builds on the synergy and strength that exist between quantitative and qualitative research approaches and also to understand a phenomenon more fully than is possible using either method alone (Creswell, 2008; Mathison, 1988; Mills, 2007). Researchers in a mixed methods research approach are able to use all of the data collection available to support studying a research problem rather than being restricted to the types of data collection normally related to qualitative approach or quantitative approach. Mixed methods research helps researchers to solve the research problems that cannot be solved by qualitative or quantitative research alone. Mixed methods provide a bridge between qualitative research and quantitative research. The divisions between qualitative research and quantitative research only serve as a restriction to research approaches and to the opportunities for collaboration (Creswell, 2010). Qualitative and quantitative data have been used in this study. The qualitative data were obtained from focus group interviews and classroom observations. The quantitative data were obtained from the Student Engagement in the Mathematics Classroom (SEMC) questionnaire. The data which were collected from these different approaches presented a coherent picture of how students' engagement changed as a consequence of the implementation the ACE teaching cycle in the Elementary Linear Algebra course at Padang State University.

The focus group in this study consisted of six students, three females and three males. They were selected randomly at the end of the course from eight groups in the class. One person represented one group. Actually, eight students were meant to be in the focus group but two of them were absent at the time of the interviews. The focus group interviews were conducted once at the end of the semester for sixty minutes. Author used a digital recorder to record all conversations. The focus group interview was conducted in the Indonesian language. The transcripts of the interviews were written in the Indonesian language, and then translated into English.

A questionnaire is an instrument that consists of the questions that are asked by the researcher directly (in face-to-face interaction) or indirectly (using papers) (O'Toole \& Beckett, 2010). There are three formats of a questionnaire based on question responses: closed questions, open questions, or both. Closed questions are difficult to construct but easy to analyse whereas open questions are easy to construct but difficult to analysis (Sarantakos, 2005). The major strength of the use of the questionnaire in research is possibly to facilitate quantitative analysis and the use of powerful descriptive and inferential statistics. The major limitation is non-response bias (Anderson, 2002) when students will not respond due to 'questionnaire fatigue'.

To collect the data through classroom observation, author used the role of a participant observer because author was involved actively in the teaching and learning process as well as the researcher. In this observation, besides making notes about what happened in the class author also used audio digital recorder to record students' voices in the discussion. The discussions among students in three groups (Group B, Group C, and Group D) were recorded during the semester (12 weeks). These groups were selected randomly from eight groups at the beginning of the semester. Every week, the discussions of only one group were recorded. For analysis purposes, author used two records of Group B discussions (discussion on week 2 and week 6). Students' communication during discussions was transcribed verbatim and then was translated into English.

The questionnaire that the author used was a student engagement scale based on the Student Engagement in the Mathematics Classroom (SEMC) questionnaire (Kong et al., 2003). The SEMC questionnaire comprises three constructs: cognitive, affective and behavioural engagement. The construct of cognitive engagement is closely related to approaches to learning namely, surface strategy, deep strategy, and reliance. Affective engagement implies a sense of belonging and an acceptance of the goals of the learning process. It involves interest, achievement orientation, anxiety and frustration. Behavioural engagement relates to students participation, attentiveness and diligence (Kong et al., 2003). The questionnaire was translated into the Indonesian language to accommodate the language needs of the participants. The researcher in this study did not investigate the validity and reliability of 
the Indonesian version of the questionnaire, because the main intention of using the questionnaire in this study was to triangulate with other data as an indication of engagement. This questionnaire was administered to participants on two occasions, before (as pre-test) and after (as post-test) the implementation of the ACE teaching cycle in the Elementary Linear Algebra course.

\section{Participants of the Study}

In the January-June 2011 semester, there were two classes of the Elementary Linear Algebra course in the Mathematics Education Study Program. Author was required to teach one class and the other class was taught by another lecturer. All the 37 students in my class became the participants in this study. They consisted of 28 females and 9 males. All of them were Year 2 students of the Mathematics Education Study Program of Padang State University in the academic year 2010/2011. Their ages ranged from 19 to 22 years. The majority of the participants came from West Sumatera province, the province where the university is located.

\section{Teaching and Learning Procedure}

The course used a teaching and learning model or instructional treatments based on the constructivist approach which is called the ACE (Activity, Classroom Discussion, Exercises) teaching cycle (Dubinsky, 2001). The first step in this cycle is 'activity'. The lecturer gives students the opportunity to do activities that relate to the topic that will be discussed in the next session. This activity encourages students to explore their previous knowledge in order to build new desired understandings (Dubinsky, 2001). In this study, author used 'concept mapping activity' in every weekly lesson. Before students created the concept maps, they were asked to learn the topics individually first so that they had knowledge about these topics. Without having knowledge about the topics students would not be able to create the concept maps. The next step was 'classroom discussion' (cooperative learning model) that provides a social context in which the students could work together to solve mathematics problems that were given by the lecturer. Finally, an 'exercise' was assigned to be done for homework. In this part, students practised mathematics problem solving and were engaged in reflection to enhance their metacognition. Related to this, students were given activities before class (outside of class), in the class, and after class (outside of class).

Activities before class: students studied the course topics individually through reading sections of the textbook and then they worked in their small groups ( 2 or 3 members) to produce a mathematics concept map about the topics. These topics were the course materials that would be discussed in the next classroom meeting. The topics were something new for the participants. Through this concept maps activity, the students were expected to have knowledge about the topics. So, they could come to class with confidence and could make their contributions in discussions.

Before the course begun, every student was required to have at least the main textbook of the course, Elementary Linear Algebra written by Howard Anton in Indonesian (Anton, 2004). The lecturer ensured that all students had this textbook; students who did not have the textbook could borrow it from the mathematics department library. This textbook became the main source for them in learning individually and to create the concepts maps.

Students created the concept maps through the discussions in their small groups. They created the maps outside the class. They arranged by themselves when, where, and how long they would work to create the concept maps. The groups comprising two or three students were formed based on the ease of their meeting outside the class. For this reason, students were asked to form the groups with their close friends or their neighbours where they lived.

Activities in classroom: there were four main teaching and learning activities which were designed to be implemented in the classroom. They were as follows: the presentation and discussion of concept maps, lecturer presentation, group discussions, and classroom discussion (classroom discussion was intended 
to solve the problems that emerged from group discussions). The time allocation that was stipulated by the Mathematics Education Program Study curriculum for the course to do teaching and learning activities was 150 minutes per week.

The presentation and discussion of mathematics concept maps was done at the beginning of the class, when it took about 15 to 20 minutes. Only one group had the opportunity to present the concept map in front of the class. The presenting group was chosen one week before the due date, except for concept map presentation in week 2 when the group was selected during the lesson. After the presentation, the activity continued by a discussion about the concept map.

The next class activity was mathematics content presentation by the lecturer. This presentation took about 40 to 60 minutes. During this time, the lecturer had the opportunity to present the mathematics topics for that week. The materials which were explained by the lecturer were not new for students anymore, because they had interacted with the topics through the concept maps activity, creating and presenting the concept maps. So, through this presentation, students had the opportunity to acquire deeper understanding of the topics. Students were also given the opportunity to raise their questions or comments on specific issues about the learning of these topics.

The next activity was group discussion. All students in the class were divided into eight groups. Each group comprised four, five, or six students. In the groups, they discussed the solving of mathematics problems that enabled them to apply the concepts and algorithms that they had studied. These mathematics problems were intended to explore students' understanding of the topics. All of the problems were exercises from the Elementary Linear Algebra textbook (Anton, 2004). This session took about 50 to 70 minutes.

Each group discussion session was followed by a classroom discussion session. In this stage, they discussed the issues that emerged from the group discussions. For example, if one group couldn't solve a problem then the group could propose the problem be discussed together in the class. During this discussion, all students in the class had the opportunity to share their ideas and experiences in solving the problem. This session took about 20 to 30 minutes.

Activities after class: Students learnt by completing two homework assignments namely, a problemsolving exercise and writing a reflective journal. These assignments were related to the mathematics materials that had been discussed during the week. So, students acquired knowledge and experience through completing these two assignments.

The type of mathematics problems that were solved by students in this session was the same as those that were given for group discussions in class. All the problems were also selected from the exercise sets in the Elementary Linear Algebra textbook (Anton, 2004). To complete the problem-solving exercises, students worked in their small groups, the same groups as when they completed the concept maps. The report of their work had to be submitted at the beginning of the class in the following week. By doing these exercises, students were expected to be able to apply their mathematics knowledge to solve the problems enabling them to improve their understanding.

Students worked individually to complete their reflective journals. Their report had also to be submitted at the beginning of the next class. As a result of doing these reflective journals, students were expected to be able to evaluate all topics that they had learnt in the week so that they could be aware of which parts that they understood well and which parts were difficult to understand.

\section{RESULTS AND DISCUSSIONS}

Students' engagement is a psychological investment in and effort directed toward learning, understanding, or mastering the knowledge, skills, or crafts that academic work is intended to promote (Newmann \& Lamborn, 1992). D'mello (2008) added that engagement involves student's willingness, need, desire and compulsion to participate in, and be successful in, the learning process. It is an 
important issue in teaching because it affects how much students learn on a daily basis. The engagement depends greatly on students' interest and the teacher's ability to create an environment that invites students to learn (D'mello, 2008; Tomlinson, 2002). In this study, the degree of student engagement in the classroom was evidenced by three domains namely, cognitive engagement, affective engagement, and behavioural engagement (Caulfield, 2010; Chapman, 2003). The data sources for these domains were a questionnaire, focus group interviews, and classroom observations.

According to Rotgans and Schmidt (2011) cognitive engagement is a psychological condition where students do a lot of effort to truly understand a topic and in which students persist with studying over a long period of time. The cognitive engagement is closely related to academic involvement or approaches to learning. The three approaches to learning namely, surface strategy (closely associated with lower levels of learning outcomes - memorisation, practising, handling tests), deep strategy (closely related to higher levels of learning outcomes - understanding the question, summarising what is learnt, connecting knowledge with the old ways of learning), and reliance (Biggs, 1978; Kong et al., 2003).

Students' affective engagement is defined by students feelings, attitudes, perceptions, and reactions to the learning environment, for example, high level of interest, enjoyment, or positive attitude towards learning (Archambault et al., 2009; Chapman, 2003). According to Miserandino (1996), and Kong et al. (2003) students' affective engagement can be seen through four dimensions namely, interest, achievement orientation, anxiety, and frustration.

According to Archambault et al. (2009), behavioural engagement is a psychological experience that concerns students' active involvement in classroom activities. Behavioural engagement is closely related to student's participation in the classroom. Active participation in the classroom is demonstrated by: taking initiative in the group and classroom, becoming involved in the classroom activities, asking questions, regularly attending class, and comprehensively completing assignments (Chapman, 2003; Skinner \& Belmont, 1993). According to Kong et al. (2003), students' behavioural engagement in learning could be seen through two aspects, namely; attentiveness and diligence.

\section{Students' Cognitive Engagement}

This section discusses analysis of data on three aspects of students' cognitive engagement: surface strategy, deep strategy, and reliance. Focus of the analysis is to evaluate the effect of the use of the ACE teaching cycle on the three aspects of students' cognitive engagement. The results of this analysis came from data related to focus group interviews and the closed questionnaire.

\section{Surface strategy aspect of cognitive engagement}

As a mathematics lecturer, I always found students used surface strategy (the strategy that relates to lower levels of learning outcomes like memorisation) in their learning process. By implementing the ACE teaching cycle in my teaching practice in the Elementary Linear Algebra course, I hope that the extent of the use of surface strategy by the students decline and the extent of the use of the deep strategy increases.

In the learning process using the ACE teaching cycle that was implemented in the Elementary Linear Algebra course, I also found that students still used surface strategy in their learning process like memorizing the formulas, definitions, theorems, and the proofs of theorems. They used this strategy in order to stay connected with the topics of the course because the contents of the course contained definitions, formulas, and theorems.

In classroom observations of discussions of Group C in Week 4, Diah said, "A is a matrix 2x2, so to find $\mathrm{A}^{-1}$ we can use the formula". The use of the formula is one alternative to find the solution to the problem. Here, Diah tended to use the formula that was available to solve the problem. The strategy that she used 
Table 2. Descriptive statistics for the surface strategy subscale of the SEMC in the pre-test and post-test $(\mathrm{n}=37)$

\begin{tabular}{lcccc}
\hline \multirow{2}{*}{ No. of items } & \multicolumn{2}{c}{ Pre-test } & \multicolumn{2}{c}{ Post-test } \\
\cline { 2 - 5 } & Mean & Standard deviation & Mean & Standard deviation \\
\hline 7 & 2.98 & 1.02 & 2.92 & 0.89 \\
\hline
\end{tabular}

could be categorized as a surface strategy in cognitive engagement because she just needed to memorize the formula and apply it to the problem.

The use of surface strategy in learning was also revealed by Vera in one of the focus groups. Vera said, "When I had difficulty to understand a definition or a theorem, then I would do memorize the definition or the theorem." Definitions and theorems are two important terms in mathematics. Sometime, students found difficulty to understand them well in a short time. This fact encouraged some students to memorize them in their effort to keep up with the lesson, like what was revealed by Vera. The strategy that has been used by Vera could also be categorized as a surface strategy of cognitive engagement.

Another fact that was revealed by students related to the use surface strategy in learning was revealed by Yanti in one of the focus groups. "I would do memorize when I found terms which difficult for me to understand. For example, I sometime found hard to understand some steps of a theorem proof, so I memorize the steps." The understanding of proving of a theorem is very important for students to know how a theorem is build up, but sometime students get difficulty to understand the proof of the theorem as experienced by Yanti. To keep connected with the theorem some students did memorize the proof of the theorem like what Yanti did because the theorem was part of the content of the course that should she learnt. This was a surface strategy of cognitive engagement.

However, although surface strategy is related to lower levels of learning outcomes, this strategy still showed students' engagement in learning through memorizing various facts and rules in mathematics (Kong et al., 2003). Through using this strategy, they tried to understand the topics being studied despite the fact that such material was difficult for them to understand. By memorizing these facts it enabled them to be still engaged in the lessons.

The information about students' surface strategy of cognitive engagement was also obtained from the closed questionnaire. The questionnaire was administered to the participants on two occasions, before and after the use of the ACE teaching cycle approach. The main intention of the qualitative data from this questionnaire was to evaluate the effect of the use of the approach. Tables 2 and $\mathbf{3}$ present the results of the analysis of students' responses to the questionnaire about the surface strategy aspect of cognitive engagement in the pre-test and post-test.

As shown in Table 2 the mean value of surface strategy subscale in the post-test (2.92) was slightly lower than that in the pre-test (2.98). This result was consistent with what I had expected, i.e., there was a decline in students' use of the surface strategy in the mathematics learning process. The use of the ACE teaching cycle had encouraged students to be involved in a series of learning activities in a mathematics topic. This gave students more opportunity to learn more widely and deeply so that it resulted in a decrease in the use of surface strategy which was previously used by students. More details about this result can be seen in Table 3 .

In Table 3, there is a decreasing mean value for several items while the mean value of others increased. The highest decline occurred for item 1, "I find memorising formula is the best way to learn mathematics." The highest increase could be seen in item 4, "In mathematics learning, it is very useful to memorise the methods for solving problem." This fact indicated the change in how students used the memorizing strategy in learning. Before the use of the ACE teaching cycle, students tended to memorize formulas, while as a result of learning using the ACE teaching cycle students tended to memorize the method for solving problems. In terms of surface strategy, memorizing the method is more complex than memorizing the formula. This showed that students engaged more in learning when they 
Table 3. Mean of the students' answers to each item of the surface strategy subscale of the SEMC in the pre-test and post-test

\begin{tabular}{llcc}
\hline \multirow{2}{*}{ No Items } & \multicolumn{2}{c}{ Mean } \\
\cline { 2 - 3 } 1 & I find memorising formula is the best way to learn mathematics. & Pre-test & Post-test \\
2 & In learning mathematics, I prefer memorising all the necessary formulas rather than understanding & 2.65 & 2.78 \\
& & 2.70 \\
& the principles behind them. & 2.76 & 2.65 \\
3 & I think memorising the fact and detail of a topic is better than understanding it holistically. & 2.86 & 3.22 \\
4 & In mathematics learning, it is very useful to memorise the methods for solving problem. & 3.22 & 3.16 \\
5 & In mathematics learning, I prefer memorising different methods of solution; this is very effective way & & \\
& of learning. & 4.14 & 3.73 \\
6 & I think the best way of learning mathematics is to memorise facts by repeatedly working on & & 2.03 \\
& mathematics problems. & 2.24 \\
7 & I think memorising mathematics is more effective then understanding it.
\end{tabular}

memorized the method of solving a mathematics problem compared to when they memorized formulas to solve a problem.

\section{Deep strategy aspect of cognitive engagement}

The purpose of analysing data in this section is to evaluate the effect of the implementation of the ACE teaching cycle in the Elementary Linear Algebra course on the deep strategy aspect of students' cognitive engagement. Deep strategy is closely related to higher levels of learning outcomes understanding the question, summarising what is learnt, applying knowledge, connecting knowledge with the old ways of learning, etc. As a lecturer and researcher in this study, I hoped that the use of the ACE teaching cycle will have positive impact on the deep strategy aspect of cognitive engagement. The data for this analysis came from focus group interviews, classroom observations, and the closed questionnaire.

Some of the students' responses that were identified from the focus group interviews that related to the deep strategy aspect as consequence of the use of the ACE teaching cycle in the Elementary Linear Algebra course are discussed below.

Zola said that,

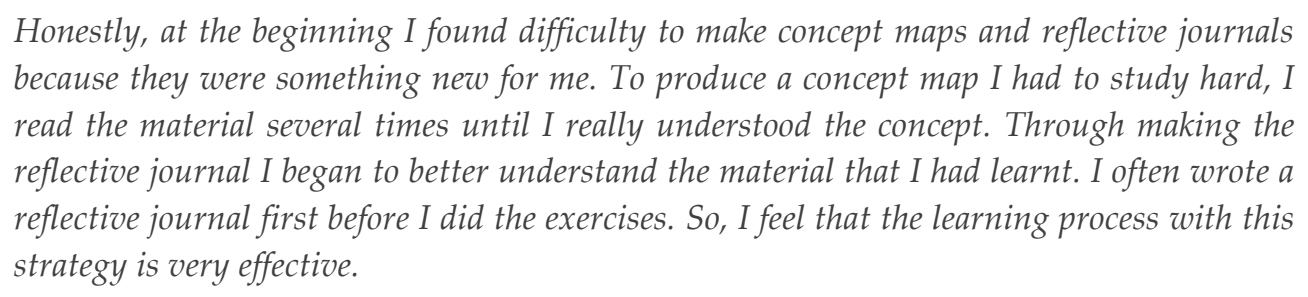

The use of the ACE teaching cycle in the Elementary Linear Algebra course has produced a positive impact on how Zola learnt the topics, so that he could get in-depth understanding of the materials. This is possible because he learnt the same topic through several learning activities. He studied hard so that he was able to apply his knowledge to produce concept maps, learnt from the lecturer's explanations, discussed in the group, wrote reflective journals, and completed exercises. This series of learning activities improved his understanding about the topic. What has been shown by Zola could be categorized as a deep strategy of cognitive engagement.

Febi revealed in the focus group about the use of the ACE teaching cycle:

With this method (ACE teaching cycle), I have to learn first before coming to class. Through this method, before we made a concept map we had to first learn by ourselves and then discuss with friends. If we didn't understand a concept we can't produce a concept map. 
Febi revealed that this method had accommodated her to learn before class. She tried to understand the material well. She realized that understanding the topics well would facilitate her to be able to create concept maps and to discuss in the class. The discussion activity gave them chance to share knowledge with each other.

Further, Febi also revealed that,

Through discussing in the class we shared information and knowledge. I got the explanation
not only from the lecture but also from friends. Through journal writing I could review and
summarize the topics and realized which parts I have understood and which parts were
difficult. My understanding about the materials became deeper through doing all
assignments.

The implementation of the ACE teaching cycle had helped Febi to get better understanding of the materials. She benefited from group discussions, writing reflective journals, and completing all assignments. Through learning by herself she knew which parts she was able to understand and which parts were hard to understand. As a result, she knew what contribution she could make and what kind of help that she expected to receive from other friends in discussions. Group discussions enabled her to share and change ideas, while writing the journal enabled her to review all topics. What has been revealed by Febi reflected that she used deep strategy of cognitive engagement in learning.

Still on focus groups, Budi also revealed his response related to deep strategy of cognitive engagement:

\begin{abstract}
Before class, I learnt the materials and together with my partner we applied what we have learnt to create the concept map. In the classroom, we discussed the materials. This approach encourages me to study hard. In the conventional classroom, there is no concept map, and there is no reflective journal. There are only exercises to be done. I had allocated more time to learn with this approach.
\end{abstract}

The use of the ACE teaching cycle approach has facilitated Budi to learn by himself and apply his knowledge to complete the concept maps task. The approach has also encouraged him to study hard and he allocated more time to learn. Budi has also shown that he used the deep strategy of cognitive engagement in learning.

What have been revealed by Zola, Febi, and Budi indicated that they had used deep strategy in their learning process. Through the use of the ACE teaching cycle in the Elementary Linear Algebra course they had opportunities for summarising what was learnt, applying knowledge, connecting knowledge, and using more time in learning. The use of this strategy enabled them to acquire deep understanding of the topics, because this strategy encouraged them to learn intensively.

The qualitative data that related to the deep strategy aspect of cognitive engagement could also be seen through classroom observations. In the Group C discussion during Week 4, Desi revealed an alternative way to prove that the identity $(A B)^{2}=A^{2} B^{2}$ is not valid for any square matrices. Desi said, "I think, we can also prove it using a counter example, we can take two particular $2 \times 2$ matrices that show that the identity is not valid". Before Desi proposed her idea her group had arrived at a solution to the problem. She was not satisfied with the solution that her group had suggested. The alternative solution that was proposed by Desi would add extend their insights to other ways of solving the problem. Desi has shown that she has used deep strategy of cognitive engagement in learning.

The data about deep strategy aspect of cognitive engagement also came from the questionnaire. Tables 4 and 5 present the mean of the students' answers to each item in the pre-test and post-test. Overall, the mean value and standard deviation of the deep strategy aspect of cognitive engagement can be seen in Table 4. 
Table 4. Descriptive statistics for the deep strategy subscale of the SEMC in the pre-test and post-test $(\mathrm{n}=37)$

\begin{tabular}{lcccc}
\hline \multirow{2}{*}{ No. of items } & \multicolumn{2}{c}{ Pre-test } & Post-test \\
\cline { 2 - 5 } & Mean & Standard deviation & Mean & Standard deviation \\
\hline 7 & 3.39 & 0.88 & 3.50 & 0.78 \\
\hline
\end{tabular}

Table 5. Mean of the students' answers to each item of the deep strategy subscale of the SEMC in the pre-test and post-test

\begin{tabular}{|c|c|c|c|}
\hline \multirow{2}{*}{\multicolumn{2}{|c|}{ No Items }} & \multicolumn{2}{|c|}{ Mean } \\
\hline & Items & \multirow{2}{*}{$\frac{\text { Pre-test }}{3.22}$} & \multirow{2}{*}{$\frac{\text { Post-test }}{3.19}$} \\
\hline 1 & When I learn mathematics, I would wonder how much the things I have learnt can be applied to real life. & & \\
\hline 2 & $\begin{array}{l}\text { When I learn new things, I would think about what I have already learnt and try to get a new } \\
\text { understanding of what I know. }\end{array}$ & 3.65 & 3.84 \\
\hline 3 & $\begin{array}{l}\text { When I read mathematics textbook, I would try to pick out those things which should be thoroughly } \\
\text { understood rather than just reading next through. }\end{array}$ & 3.97 & 4.05 \\
\hline 4 & $\begin{array}{l}\text { I would try to connect what I learned in mathematics with what I encounter in real life or in other } \\
\text { subjects. }\end{array}$ & 3.41 & 3.32 \\
\hline 5 & I would spend out of class time to deepen my understanding of the interesting aspects of mathematics. & 3.16 & 3.35 \\
\hline 6 & $\begin{array}{l}\text { In learning mathematics, I always try to pose questions to myself and these questions would help me } \\
\text { understand the core of mathematics. }\end{array}$ & 3.19 & 3.32 \\
\hline 7 & I would use my spare time to study the topics we have discussed in the class. & 3.16 & 3.41 \\
\hline
\end{tabular}

As shown in Table 4, the mean value of all items in the deep strategy subscale of cognitive engagement in the post-test (3.50) was higher than that in the pre-test (3.39). This trend suggests that the implementation of the ACE teaching cycle in the Elementary Linear Algebra course resulted in positive effect on the use of deep strategy in students' learning process.

From Table 5, it can be seen that five of the items (item 2, 3, 5, 6, and 7) displayed an increase in the mean value from the pre-test to the post-test. These items were related to students' efforts to deepen their understanding of the materials. So, there was an increase in the deep strategy that was used by students to understand the topics, especially on the five items. This result was probably caused by the ACE teaching cycle approach that gave the opportunity to students to think about what they had already learnt through the reflective journals homework, to learn from the textbook to prepare them to create concept maps, to explore the material through discussions, and to complete exercises inside and outside the classroom.

However, two of the seven items (item 1 and 4) showed a decreasing mean value in students' responses from the pre-test to the post-test. These items were related to the application of mathematics in real life and to other subjects. This result may have been due to the material of the subject that did not explicitly involve the use of the concepts in real life or the role of the concepts in other subjects. Most concepts of this Elementary Linear Algebra course are about pure mathematics like linear equation systems, vectors, matrix, vector spaces, and inner product space. This condition may be the cause of the slight decrease in the mean values of the two items.

So, analysis of both qualitative and quantitative data showed that the use of the ACE teaching cycle in the Elementary Linear Algebra course increase students' deep strategy of cognitive engagement in the same direction as what researcher had expected.

\section{Reliance aspect of cognitive engagement}

In this part I will discuss the results of the analysis about students' reliance in learning. The purpose of this analysis is to evaluate the effect of the implementation of the ACE teaching cycle in the Elementary Linear Algebra course on students' reliance. The data for this aspect was obtained from focus group interviews, classroom observations and the questionnaire. Some of the students' responses to these 
issues that were identified in the focus group interviews about reliance and independence in mathematics learning will be presented first.

In focus group Febi revealed that,

The ACE teaching cycle has changed my approach in learning mathematics. In using this approach, I have to learn first before coming to class. Through this method, we were first asked to draw a concept map; but before we developed the concept map we had to first learn by ourselves. If we didn't understand a concept, we couldn't produce a concept map. So, through this method I have to learn by myself and not depend on the lecturer's explanation.

Febi revealed that the use of the ACE teaching cycle in the Elementary Linear Algebra course had an effect to her way in learning. The strategy that had been implemented facilitated her to improve her ability to study by herself. The concept maps task that was completed by students before class has encouraged her to learn the topics before she was involved in creating the concept maps. As a result, she had known the topics before these were presented by the lecturer in the class. So, her dependence on the lecturer's explanations decreased.

Still in the focus groups, Yanti also expressed her opinion about the reliance aspect:

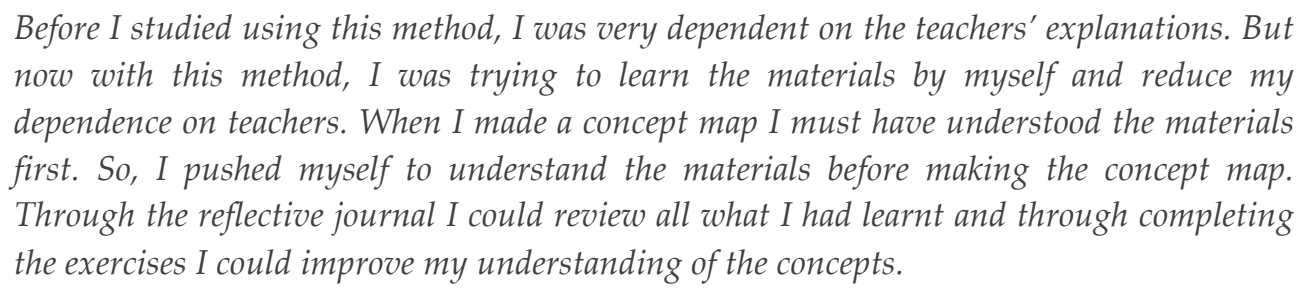

The use of the ACE teaching cycle in the Elementary Linear Algebra course has resulted in a different learning experience for Yanti. In this course, she had the opportunity to learn not only from the lecturer's explanations but also from other activities like reading textbooks, creating concept maps, discussing in groups, writing reflective journals, and completing exercises. Using this strategy, her dependence on the lecturer's explanations in the class has been reduced. As a consequence of this, her ability to construct knowledge by herself has improved.

Zola also stated his opinion in the focus group as follows:

I think the ACE teaching cycle approach is suitable for my type of learning; when I am given tasks I will do them seriously. Honestly, at the beginning I found difficulty to make concept maps and reflective journals because they are something new to me. To produce a concept map I have to study hard; I read the topics several times until I really understood the concept. Through writing the reflective journal I become to better understand the material that I had learnt. I often wrote a reflective journal first before I attempted the exercises. So, I feel that the learning process with this strategy is very effective.

Here, Zola revealed two things: reliance and independence. He said that he would learn seriously if he was given an assignment. This attitude reflected his reliance on the lecturer. The lecturer's directions were important for him to start learning, to give him ways on what should he do, and to encourage him to learn by himself. What Zola said was reasonable; without the lecturer's directions, he would not be compelled to make concept maps, to discuss in groups, to write reflective journals, and to complete exercises. On other hand, Zola also showed his independence in learning. He struggled to understand the topics by himself in order to be able to contribute in creating concept maps and discussing in his group.

The qualitative data that were revealed from students' responses in the focus group interviews revealed the increasing independence in students' learning. This fact showed that the use of the ACE teaching 


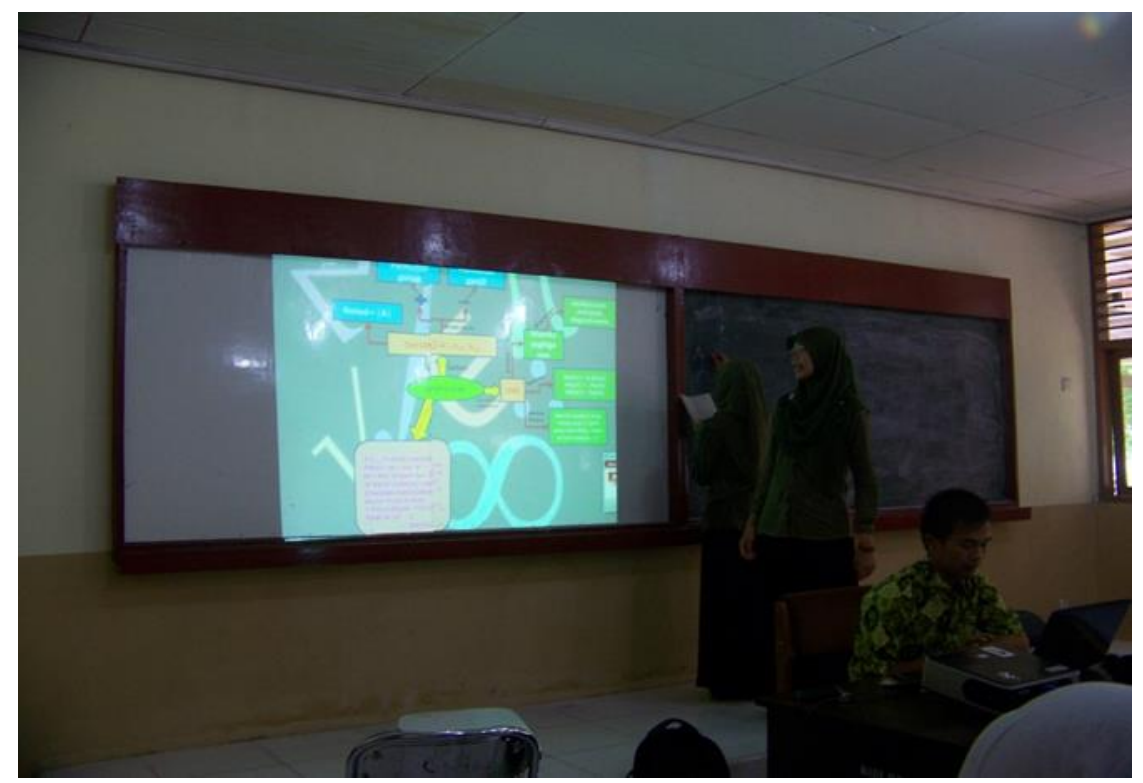

Figure 1. Group B1 presenting the concept maps about determinants

Table 6. Descriptive statistics for the reliance subscale of the SEMC in the pre-test and post-test $(\mathrm{n}=37)$

\begin{tabular}{lcccc}
\hline \multirow{2}{*}{ No. of items } & \multicolumn{2}{c}{ Pre-test } & \multicolumn{2}{c}{ Post-test } \\
\cline { 2 - 5 } & Mean & Standard deviation & Mean & Standard deviation \\
\hline 7 & 3.70 & 0.67 & 3.78 & 0.62 \\
\hline
\end{tabular}

cycle in the Elementary Linear Algebra course affects students' independence in learning. On other hand, the data also showed that students' had trust in the lecturer's instruction.

The information about students' independence in learning was also obtained from students' activities in the classroom. As an example, the researcher took concept maps presentation during Week 5 by Group B1. Concept maps presentation was a learning activity at the beginning of the class in every classroom meeting. A group was selected to present their concept maps in front of the class. The mathematics topic that they presented in Week 5 was about Determinants. Group B1 comprised three members, Eki, Vera, and Salsa. They shared the duties in presenting the concept map that they had created; Eki acted as moderator whilst Salsa and Vera acted as concept map presenters.

Salsa presented the concept map using PowerPoint. She explained the definition of determinant. Salsa also used the blackboard to provide additional explanations and examples. And then, the presentation was continued by Vera. She gave the explanation about the properties of determinants, cofactor expansion, Cramer's rule and the application of determinants. Salsa and Vera presented their concept maps that they had conscientiously in a systematic manner. What they had displayed in presenting the concept maps was the result of their efforts in learning. They had learnt the topic through learning individually and discussing in their small group to produce the concept maps. They were able to create and present the concept maps without any help from the lecturer. This showed that the use of the ACE teaching cycle approach in the Elementary Linear Algebra course has encouraged students to become independent in their learning. Figure 1 shows Group B1 presenting the concept maps about Determinants.

The data about the reliance aspect of cognitive engagement was also obtained from the questionnaire. Tables 6 and 7 provide the mean of the students' answers to each item of the reliance subscale of cognitive engagement of the SEMC in the pre-test and post-test. The overall mean value and standard deviation of the reliance aspect of cognitive engagement can be seen from Table 6 .

Overall, as shown in Table 6 the mean value of all items in the post-test (3.78) was higher than in the pre-test (3.70). This trend suggests that the implementation of the ACE teaching cycle in the Elementary 
Table 7. Mean of the students' answer to each item of the reliance subscale of the SEMC in the pre-test and post-test $(n=37)$

\begin{tabular}{llcc}
\hline \multirow{2}{*}{ No Items } & \multicolumn{2}{c}{ Mean } \\
\cline { 2 - 3 } & Pre-test & Post-test \\
\hline 1 & The best way to learn mathematics is to follow the lecturer's instructions. & 3.84 & 3.86 \\
2 & The most effective way to learn mathematics is to follow the lecturer's instruction. & 3.86 & 3.78 \\
3 & I would learn what the lecturer teaches. & 4.07 & 4.03 \\
4 & I would learn in the way the lecturer instruct me & 3.49 & 3.68 \\
5 & I would solve problems in the same way as the lecturer does. & 3.51 & 3.78 \\
6 & I solve problems according to what the lecturer teaches. & 3.86 & 3.95 \\
7 & In the learning mathematics, no matter what the lecturer says, I will follow accordingly. & 3.30 & 3.38 \\
\hline
\end{tabular}

Linear Algebra course had an influence on the increase in the reliance aspect of cognitive engagement. Most of the items of the reliance aspect of cognitive engagement relate to students' trust in the lecturer's approach to the learning process. These items were not particularly intended to reveal students' independence in learning. Specifically, the change in students' responses to each item of the reliance aspect can be seen in Table 7 .

From Table 7, it can be seen that there was an increase in the mean value in five of the seven items (item $1,4,5,6$, and 7). These items relate to the instructions and examples that were given by the lecturer during the teaching and learning process. Based on these students' responses, it appears that as consequence of the use of the ACE teaching cycle students tended to follow the directions and examples that were given by the lecturer. Students probably expected the lecturer to give directions and advice to them on how to learn individually, to create concept maps, to discuss the mathematics problem solving, to do exercises, and to write reflective journals. All of these directions have an effect on how the students learn.

However, a decrease in the mean value was also observed for two items (items 2 and 3), with a larger decrease for item 2. The decrease in the mean value for item 2 (the most effective way to learn mathematics is to follow the lecturer's instruction) was not surprising because in the ACE teaching approach the lecturer's role in giving instructions was smaller than in the traditional approach. In ACE teaching model, the lecturer only had $40-50$ minutes out of a total of 150 minutes during each session to give the instructions in the classroom. The remaining time was used for concept maps presentation and group discussions. Students' responses to this item showed that the use of the ACE teaching cycle approach had resulted in a decline in students' reliance on lesson instructions that were given by the lecturer. In other words, the approach had increased students' independence in learning.

So, analysis of both qualitative and quantitative data showed that the use of the ACE teaching cycle approach in the Elementary Linear Algebra course increase students' independence in learning and decrease students' reliance on knowledge from the lecture directly. The data also showed an increase of students' reliance on lecturer's direction in the classroom.

\section{Students' Affective Engagement}

Affective engagement is closely related to students' reactions to the learning environment like, high level of interest, enjoyment, positive attitude towards learning, boredom, happiness, feelings of belonging, etc. (Chapman, 2003; Pierce et al., 2005). In this study, students' affective engagement would be seen through four dimensions namely, interest, achievement orientation, anxiety, and frustration (Kong et al., 2003; Miserandino, 1996).

\section{Interest aspect of affective engagement}

The purpose of analysing the data in this section was to study the change on the interest aspect of students' affective engagement before and after the use of the ACE teaching cycle in the Elementary Linear Algebra course. The researcher expected that the use of this approach would improve students' 
Table 8. Descriptive statistics for the interest subscale of the SEMC in the pre-test and post-test $(\mathrm{n}=37)$

\begin{tabular}{lcccc}
\hline \multirow{2}{*}{ No. of items } & \multicolumn{2}{c}{ Pre-test } & \multicolumn{2}{c}{ Post-test } \\
\cline { 2 - 5 } & Mean & Standard deviation & Mean & Standard deviation \\
\hline 6 & 4.02 & 0.76 & 4.17 & 0.69 \\
\hline
\end{tabular}

Table 9. Mean of the students' answers to each item of the interest subscale of the SEMC in the pre-test and post-test $(\mathrm{n}=37)$

\begin{tabular}{llcc}
\hline \multirow{2}{*}{ No Items } & \multicolumn{2}{c}{ Mean } \\
\cline { 2 - 3 } & Pre-test & Post-test \\
\hline 1 & In the mathematics class, I find the mathematics knowledge interesting and mathematics learning is & 4.05 & 4.27 \\
& enjoyable. & 3.95 & 4.11 \\
2 & I find mathematics learning pleasurable and I am interested in solving mathematics problems. & 4.70 & 4.68 \\
3 & I feel a sense of satisfaction when I do mathematics exercises in class. & 3.89 & 4.03 \\
4 & I am always curious to learn new things in mathematics and I find learning mathematics enjoyable. & 3.68 & 3.92 \\
5 & I feel excited when we start a new topic in mathematics. & 3.86 & 3.97 \\
6 & I am very interested to know how to solve new mathematics problems. Mathematics always gives me \\
& pleasure. & \\
\hline
\end{tabular}

interest in learning mathematics. The data for this analysis came from focus group interviews (qualitative data) and from the questionnaire (quantitative data). The qualitative data will be analysed first.

In focus groups, Eki revealed his interest in learning mathematics using the ACE teaching cycle approach by saying, "I became more interested in studying mathematics. One important thing was that I was ready to attend classes." Explicitly, Eki revealed that the strategy that was implemented in the Elementary Linear Algebra course affected his interest in learning. He also stated that the ACE teaching cycle had encouraged him to learn before class, so he could participate well in the class.

Next, Budi also revealed his opinion that relates to interest: "This approach is very suitable for my learning style, because the approach gave attention to self-learning." This Budi's response showed that he had improved interest to be involved in learning Elementary Linear Algebra using the ACE teaching cycle because the approach accommodated the procedures that he liked. As consequence of his interest, he felt that learning mathematics was an enjoyable activity and encouraged him to be fully involved in learning, although at first he felt awkward. Related to this, Bayu stated that "From one week to another week I became familiar with this method. Although at the beginning, I felt worried about how to produce a good concept map or how to make a good reflective journal."

In another instance in focus group interviews, Yanti revealed her interest by saying, "About the time for learning, my learning time increased with this method and I became more intensive in learning". Allocating more time for learning would give her the opportunity to understand a topic better. What Yanti said reflected her attention to focus in learning. This fact showed that Yanti had improved interest in learning as a consequence of the use of the ACE teaching cycle approach in the Elementary Linear Algebra course.

Quantitative data from the closed questionnaire also revealed the interest aspect of students' affective engagement. Tables 8 and $\mathbf{9}$ summarise the mean of the students' answers to each item of the interest subscale of the SEMC in the pre-test and post-test. Overall, mean values and standard deviations of the interest aspect of affective engagement are given in Table 8 .

As shown in Table 8, the mean value of all items in the post-test (4.17) was higher than that in the pretest (4.02). This finding suggests that the implementation of the ACE teaching cycle in the Elementary Linear Algebra course had the same effect as the researcher's expectations about students' interest in learning mathematics. More details about this outcome could be seen in Table 9 . 
In Table 9, it is seen that the mean value increased for almost all items. The highest increase was in item 5: "I feel excited when we start a new topic in mathematics." The use of the ACE teaching cycle approach had influenced students' readiness to learn new topics. They were happy to learn a new topic. Their pleasure to learn new topics was probably caused by the approach used in the teaching and learning process that facilitated them to directly and intensively interact with the topics of the course so that they had the desire to learn other topics further. This fact is different from my previous experience as a lecturer, where most of the students felt worried to learn a new topic.

The decrease in the mean value occurred only for item 3: "I feel a sense of satisfaction when I do mathematics exercises in class". Mean value in the pre-test was 4.70 while in the post-test the mean was 4.68. The difference of between these two means is very small, with the two scores almost having the perfect value of 5 , suggesting that most of the students chose the option 5 (almost always) for item 3 in the pre-test and post-test. In the pre-test, most of the students indicated that they felt a good sense of satisfaction when they did mathematics exercises in class before the ACE teaching cycle approach was implemented. In the post-test, there was a similar trend in students' responses to the item. So, it may be concluded that most of the students had a good sense of satisfaction in doing mathematics exercises before and after the use of the ACE teaching cycle approach.

So, the analysis of both qualitative and quantitative data showed that the use of ACE teaching cycle had the same improved effect on the students' interest in learning mathematics as that expected by the researcher.

\section{Achievement orientation aspect of affective engagement}

The purpose of analysing data in this section is to evaluate the effect of the use of the ACE teaching cycle in the Elementary Linear Algebra course on the achievement orientation aspect of students' affective engagement. As a researcher, my expectation was that the use of the approach would have a positive effect on students' achievement orientation. The analysis was performed on the qualitative and quantitative data. The qualitative data would be analysed first.

In focus group interviews, students expressed their effort in learning like what Vera said,

The difficulty that I found in learning with this method was that it was difficult to understand the new materials, because I had to learn the materials by myself first. I had to learn slowly to understand the concepts. So, I needed much time to understand the materials. Sometime I learnt the materials from the textbook over and over again until I understood.

Vera realized that she faced difficulty in learning, especially to learn new topics. This condition did not prevent her from continuing learning. Although slower, she continued learning to understand the material. This behaviour showed that she displayed achievement orientation in learning.

Still on focus group interviews, Budi also revealed his achievement orientation by saying that "This approach encourages me to study hard. I had allocated more time to learn with this approach." He expressed that the implementation of the ACE teaching cycle in the Elementary Linear Algebra had encouraged him to be serious in learning so that he could achieve his learning aims. By working hard and allocating more time gave him the opportunity for him to learn more concepts and to deepen his understanding.

The quantitative data from questionnaire also revealed about the achievement orientation aspect of affective engagement. Tables $\mathbf{1 0}$ and $\mathbf{1 1}$ summarise the mean values of the students' responses to each item of the achievement orientation subscale of the SEMC in the pre-test and post-test. The overall mean values and standard deviations of the achievement orientation subscale can be seen in Table $\mathbf{1 0}$.

Students' responses to the achievement orientation items, shown in Table 10, revealed that most of the students selected option 4 (often) or 5 (almost always) for all items. This can be seen from the mean for 
Table 10. Descriptive statistics for the achievement orientation subscale of the SEMC in the pre-test and post-test $(\mathrm{n}=37)$

\begin{tabular}{lcccc}
\hline \multirow{2}{*}{ No. of items } & \multicolumn{2}{c}{ Pre-test } & \multicolumn{2}{c}{ Post-test } \\
\cline { 2 - 5 } & Mean & Standard deviation & Mean & Standard deviation \\
\hline 6 & 4.54 & 0.63 & 4.50 & 0.59 \\
\hline
\end{tabular}

Table 11. Mean of the students' answers to each item of the achievement orientation subscale of the SEMC in the pre-test and post-test $(n=37)$

\begin{tabular}{llcc}
\hline \multirow{2}{*}{ No Items } & \multicolumn{2}{c}{ Mean } \\
\cline { 2 - 3 } & Pre-test & Post-test \\
\hline 1 & Though mathematics learning is tough, I feel happy when I can finish the tasks. & 4.46 & 4.49 \\
2 & Though mathematics learning is boring, I am happy when I get good result. & 4.54 & 4.41 \\
3 & Learning mathematics is tough, but to get good result, the effort is worthwhile. & 4.43 & 4.49 \\
4 & Learning mathematics is tough, but I am satisfied when I get good result after making an effort. & 4.73 & 4.59 \\
5 & Learning mathematics is tough, but I am happy as long as I can get good result. & 4.54 & 4.46 \\
6 & Though mathematics learning is tough, I get a sense of satisfaction when I get good result. & 4.54 & 4.54 \\
\hline
\end{tabular}

both the pre-test and the post-test (4.54 and 4.50). These mean values showed a slight decrease in students' responses to the achievement orientation aspect of affective engagement. This result was not in accordance with the expectations of the researcher who had expected an increase in this aspect, but based on both the mean values it can be said that the students displayed satisfactory achievement orientation before and after the use of the ACE approach. As a researcher I saw that there was no significant change in the achievement orientation aspect of affective engagement. In other words, the implementation of the ACE teaching cycle in the Elementary Linear Algebra course did not change students' achievement orientation significantly. Further details about students' responses in both the pre-test and post-test can be seen in Table 11.

Table 11 shows that the mean value for all items in the pre-test and post-test were above 4 . This trend suggests that most students had good achievement orientation in learning before and after the implementation of the ACE teaching cycle approach and the use of the approach was able to maintain the students' achievement orientation in learning.

So, qualitative data revealed that the use of the ACE teaching cycle had encouraged students to study hard. While the quantitative data did not show an increase in the mean value from the pre-test to the post-test on all items, the mean values were still high. This fact suggests that students had strived to understand material more but still got the same reward from their success.

\section{Anxiety aspect of affective engagement}

The purpose of analysing the data in this section was to evaluate the effects of the use of the ACE teaching cycle in the Elementary Linear Algebra course on the anxiety aspect of students' affective engagement. Author expected that the use of this approach would result in a decrease in students' anxiety levels in learning mathematics. The data for this aspect came from focus groups (qualitative data) and the questionnaire (quantitative data). The qualitative data will be analysed first.

In the focus group interview, Zola revealed his opinion about the use of ACE teaching model that relate to anxiety in learning.

Through this approach I could share my knowledge in mathematics with other friends. I understood more if I could teach someone else. I was happy learning mathematics using this approach. This teaching model was suitable with my learning style. I just felt anxious to face the test.

Zola's opinion above reflected that the use of the ACE teaching cycle approach in Elementary Linear Algebra course did not cause him any anxiety in learning. He just felt anxious to face the test. 
Table 12. Descriptive statistics for the anxiety subscale of the SEMC in the pre-test and post-test $(n=37)$

\begin{tabular}{lcccc}
\hline \multirow{2}{*}{ No. of items } & \multicolumn{2}{c}{ Pre-test } & \multicolumn{2}{c}{ Post-test } \\
\cline { 2 - 5 } & Mean & Standard deviation & Mean & Standard deviation \\
\hline 5 & 3.49 & 0.86 & 3.46 & 0.85 \\
\hline
\end{tabular}

Table 13. Means of the students' responses to each item of the anxiety subscale of the SEMC in the pretest and post-test $(n=37)$

\begin{tabular}{llcc}
\hline \multirow{2}{*}{ No Items } & \multicolumn{2}{c}{ Mean } \\
\cline { 2 - 3 } & I find myself very nervous during mathematics test. & Prest-test \\
\hline & I am worried in mathematics examinations. & 3.22 & 3.38 \\
3 & During mathematics examinations, when I come across problems that I cannot comprehend, I will feel & 3.35 & 3.30 \\
& very nervous. & 3.43 \\
4 & I am always afraid that I will get poor result in mathematics test. & 3.78 & 3.62 \\
5 & During mathematics test, when I come across problems that I cannot solve, I will feel very anxious. & 3.68 & 3.57 \\
\hline
\end{tabular}

In focus group interviews Yanti stated,

From week to week I became more anxious, because the materials became more complicated. I have learnt the materials at home but it was still hard for me to understand. I got a lot of help from friends in my group, this made me feel safe

Yanti felt anxious because she realized that if she couldn't learn the topics properly, then she would face difficulty to follow further learning because the topics in mathematics are related to each other. But, she felt safe because she belonged to a supportive group that were ready to help her. This fact points to an indication that the use of the ACE teaching model had facilitated Yanti to reduce her anxiety in learning.

Still in the focus group other students revealed their anxiety in facing the test. Zola stated that "I always feel anxious before an examination." Next, Eki said that "I will be anxious when I can't solve a problem." Many other students are like Zola and Eki, they become anxious to face exams. Students feel anxious before and during the examination because they don't want to fail. This condition may have encouraged them to learn harder.

The data about anxiety also came from the questionnaire. All items in anxiety subscale related to test or examination. Students were required to respond to five items about the anxiety aspect of affective engagement. The questionnaire was administered to students on two occasions, before and after the implementation of the ACE teaching cycle. Tables 12 and 13 presents the means of the students' responses on the anxiety subscale of affective engagement of the SEMC in the pre-test and post-test. The overall mean values and standard deviations of the anxiety subscale can be seen in Table 12 .

Table 12 shows that the mean values in both pre-test and post-test are relatively high at 3.49 and 3.46. Most of the students selected options 3 (sometimes) or 4 (often) for all items. So, this trend suggests that the anxiety experienced by students in facing the test either before or during the use of the ACE teaching cycle approach was quite high. However, the use of the approach has resulted in a slight reduction of the students' anxiety levels. This could be seen from the mean value of the post-test mean that was slightly lower than the mean value in the pre-test. The change was practically negligible. More details about the mean values of each item of the anxiety aspect of affective engagement in the pre-test and post-test can be seen in Table 13.

In Table 13, it is seen that there was a decrease in the mean value for almost all the items. The mean value increased only for item 1 , "I find myself very nervous during mathematics test". This increase in the mean value was very significant, increasing from 3.22 in the pre-test to 3.38 in the post-test. However, as a lecturer I had expected that the level of their anxiety would have declined. I was surprised to observe this result. Why did this happen? According to Crowder (2011) the longer a student takes to prepare for a test the more nervous s/he becomes. In my teaching practice using the ACE teaching cycle 
Table 14. Descriptive statistics for the frustration subscale of the SEMC in the pre-test and post-test (n =37)

\begin{tabular}{lcccc}
\hline \multirow{2}{*}{ No. of items } & \multicolumn{2}{c}{ Pre-test } & \multicolumn{2}{c}{ Post-test } \\
\cline { 2 - 6 } & Mean & Standard deviation & Mean & Standard deviation \\
\hline 5 & 1.75 & 0.76 & 1.66 & 0.74 \\
\hline
\end{tabular}

approach, I found that students spent more time preparing for a test, similarly to what Crowder had speculated. According to Crowder (2011) the best advice to reduce nervousness when preparing for a mathematics test is by revising the mathematics concepts slowly.

So, the qualitative data suggest that the use of the ACE teaching model did not trigger students' anxiety in learning mathematics. The approach facilitated student to feel happy and safe. The qualitative and quantitative data that relate to the test suggest that students experienced some anxiety. From the quantitative data shown in Table 14, there was a slightly decreased in the mean value of students' responses in the post-test compared with their responses in the pre-test. This trend suggests that students' level of anxiety that relate to test had slightly decreased. According to Peker (2009), one of the causes of anxiety in learning mathematics is due to negative experiences in the learning process like failing a test, difficulty in understanding a concept, limited support from the lecturer, etc. So, this trend suggests that the implementation of the ACE teaching cycle in the Elementary Linear Algebra reduced the students' negative experiences in learning mathematics. This finding was similar to that of the researcher's expectations.

\section{Frustration aspect of affective engagement}

The purpose of analysing the data in this section was to evaluate the effects of the implementation of the ACE teaching cycle in the Elementary Linear Algebra course on the frustration aspect of students' affective engagement. The expectation of the implementation of the approach was that students' frustration in mathematics learning would be reduced. The data for this aspect came from focus groups (qualitative data) and the questionnaire (quantitative data).

In the focus group interviews, students were asked whether they felt frustrated when they learnt using the ACE teaching cycle approach. Some of them gave their response as follows: Budi's response, "No, I didn't feel frustrated when I learnt with this approach." Yanti revealed that, "I just felt frustrated when I couldn't solve the problem." Zola also gave his response, "I usually got frustrated when I knew that I made a mistake in the test." So generally, I could say that the students did not feel frustrated when they followed learning using the ACE teaching model.

Budi revealed that the learning activity which he followed did not cause him to feel frustrated. This suggests that Budi enjoyed the lessons and could follow the lessons well. Meanwhile, Yanti and Zola had almost similar feelings when they revealed that they felt frustrated only when they made mistakes in the test. Perhaps this is not uncommon source of frustration to most students studying mathematics.

The data about frustration were also obtained from the questionnaire. Students were required to respond to five items about the frustration aspect of affective engagement. The questionnaire was administered to students on two occasions, before and after the use of the ACE teaching cycle. The mean values and standard deviations for the items of the frustration aspect of affective engagement can be seen in Table 14.

From the descriptive statistics Table 14, the mean values of the frustration aspect of affective engagement are less than two. This finding suggests that most students selected options 1 (almost never) or 2 (seldom) from the five options that were provided. This finding suggests that the level of students' frustration in learning mathematics was low before and during the use of the ACE teaching cycle. However, the mean value decreased from 1.75 in the pre-test to 1.66 in the post-test. This trend suggests 
Table 15. Means of the students' responses to each item of the frustration subscale of the SEMC in the pre-test and post-test $(n=37)$

\begin{tabular}{llcc}
\hline \multirow{2}{*}{ No Items } & \multicolumn{2}{c}{ Mean } \\
\cline { 2 - 3 } & & Pre-test & Post-test \\
\hline 1 & I feel uncomfortable when the teacher starts a new topic. & 2.24 & 2.14 \\
2 & I am tired of learning a new topic in class. & 2.11 & 1.81 \\
3 & I do not like attending mathematics classes. & 1.51 & 1.54 \\
4 & I dislike doing mathematics. & 1.24 & 1.35 \\
5 & I am tired of learning mathematics. & 1.65 & 1.46 \\
\hline
\end{tabular}

that the level of students' frustration only slightly decreased as a result of the use of the approach. The mean value of students' responses to each item of the frustration aspect can be seen in Table $\mathbf{1 5}$.

In Table 15, it can be seen that the mean values of students' responses to each item are in the range of 1 to 2. This trend reflected the low levels of students' frustration before and during the use of the ACE teaching cycle. However, from the table it can be seen that the mean values of some items had increased but had decreased for other items. The most notable decrease in the mean value was for item 3, "I am tired of learning a new topic in class." The decrease in this mean value could have been due to the students having learnt the new topics through a series of activities that they had followed step by step. First, they read the textbook as a preparation to create the concept maps. Then, they were involved in creating the concept maps about the topics. Next, they were involved in discussions about the topic in the class. Then, they listened to the lecturer's explanations about the topics. Finally, they wrote reflective journals and completed homework exercises on the topics. So, they did not learn the new topics at one go but gradually. This approach may have had an effect on the level of the students' tiredness in learning.

So, from the qualitative and quantitative data it may be deduced that students felt frustrated in learning mathematics before and during the use of the ACE teaching cycle approach. The qualitative data revealed that the level of students' frustration during the use of the approach had only slightly decreased. This finding suggests that the use of the ACE teaching cycle had contributed to lowering of students' frustration in learning, similarly to what the researcher had expected.

\section{Students' Behavioural Engagement}

Behavioural engagement is closely related to student participation in the classroom. Active participation in the classroom is demonstrated by: compliance with classroom procedure, taking initiative in the group and classroom, becoming involved in the classroom activities, asking questions, regularly attending class, and comprehensively completing assignments (Chapman, 2003; Skinner \& Belmont, 1993). According to Kong et al. (2003), students' behavioural engagement in learning could be seen through two aspects, namely; attentiveness and diligence. These two terms will be discussed to describe students' behavioural engagement in learning.

\section{Attentiveness aspect of students' behavioural engagement}

The purpose of analysing the data in this section was to evaluate the effects of the use of the ACE teaching cycle in the Elementary Linear Algebra course on the attentiveness aspect of students' behavioural engagement. The data for this approach came from focus group interviews, classroom observations (qualitative data), and the questionnaire (quantitative data).

In the focus group, Febi revealed her attentiveness in learning using ACE teaching approach by saying,

Through discussing in the class we could share information and knowledge and through journal writing I could review the topics. I got the explanation not only from lecture but also from friends. I achieved deeper understanding of the topics through doing all tasks. 


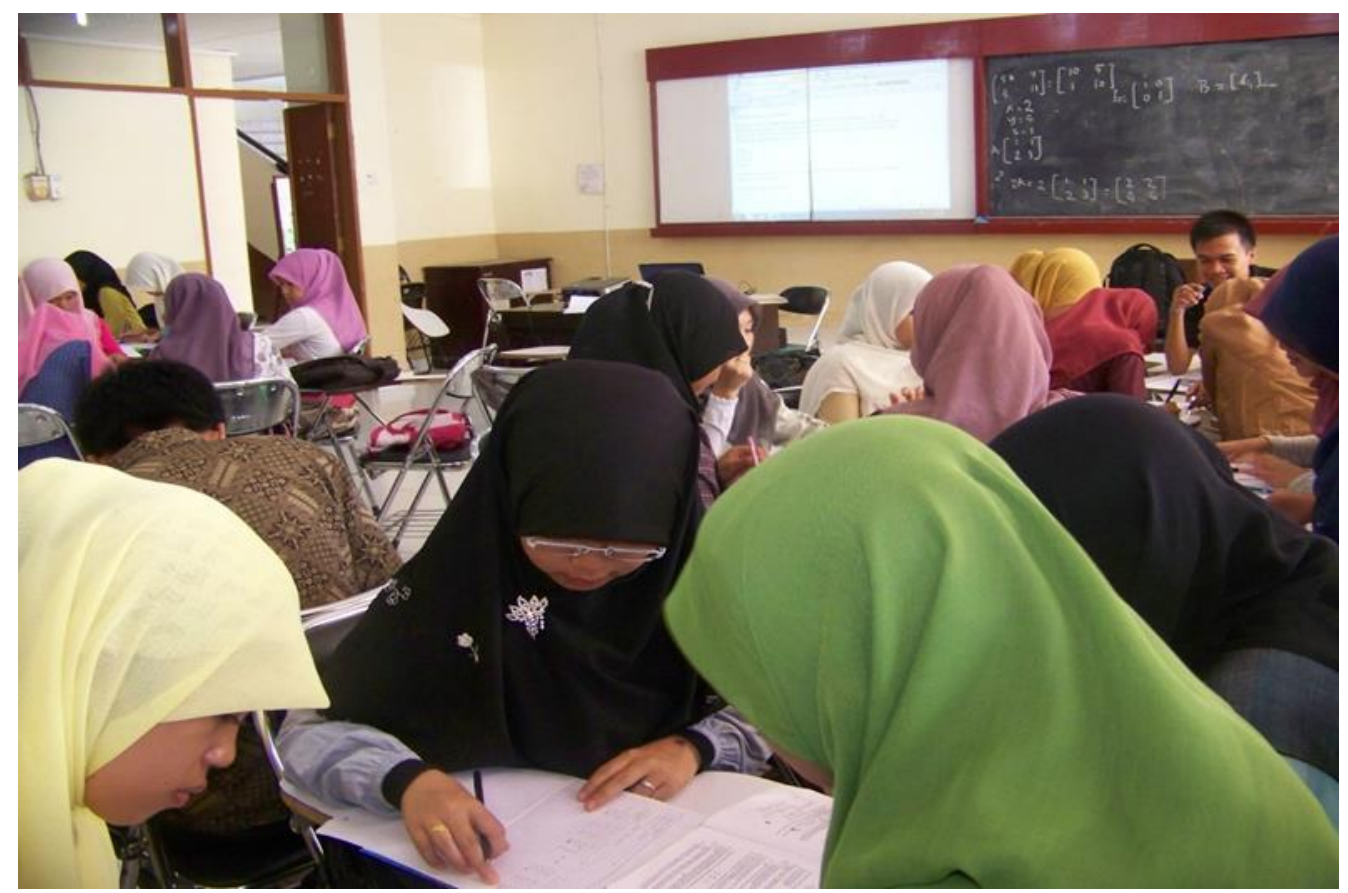

Figure 2. Classroom atmosphere when all groups were involved in discussions during Week 4

Febi stated that she involved herself actively in the learning activities, like doing all the tasks, and by being active in discussions. She also revealed that she benefited from learning with this approach by sharing ideas in discussions, reviewing the materials, and in the process achieved deeper understanding. This fact suggests that the students were engaged in the teaching and learning procedures that were implemented in the course.

Still in the focus groups, Budi said,
About discussions in the class, if we were given a lot of problems to solve then we shared the problems so that each of us could work individually first, and then we discussed them together. So, in the group there was mutual exchange of information that increased my ability to solve the problem.

Budi explained his group's strategy to discuss the problems. This practice was an indication that all of them had paid attention to be involved to solve the mathematical problems that they faced.

The attentiveness aspect of behavioural engagement could also be seen through classroom observations. Figure 2 presents the classroom atmosphere during Week 4 when all groups held discussions while solving the mathematics problems. All groups in the class were involved in active discussion. Through discussions in groups, they had the opportunity to share knowledge in their effort to solve the problems that they faced. This finding suggests that the use of the ACE teaching cycle approach had affected students' attentiveness in learning.

The data about this attentiveness aspect also came from the questionnaire. Students were required to respond to six items about the attentiveness aspect of their behavioural engagement. The questionnaire was administered to students on two occasions, before and after the use of ACE teaching cycle. The mean values and standard deviations of the students' responses to all items of the attentiveness aspect can be seen in Table 16. 
Table 16. Descriptive statistics for the attentiveness subscale of the SEMC in the pre-test and post-test $(\mathrm{n}=37)$

\begin{tabular}{lcccc}
\hline \multirow{2}{*}{ No. of items } & \multicolumn{2}{c}{ Pre-test } & \multicolumn{2}{c}{ Post-test } \\
\cline { 2 - 5 } & Mean & Standard deviation & Mean & Standard deviation \\
\hline 6 & 3.79 & 0.83 & 3.78 & 0.81 \\
\hline
\end{tabular}

Table 17. Mean of the students' responses to each item of the attentiveness subscale of the SEMC in the pre-test and post-test $(\mathrm{n}=37)$

\begin{tabular}{|c|c|c|c|}
\hline \multirow{2}{*}{\multicolumn{2}{|c|}{ No Items }} & \multicolumn{2}{|c|}{ Mean } \\
\hline & & \multirow{2}{*}{$\begin{array}{c}\text { Pre-test } \\
3.92\end{array}$} & \multirow{2}{*}{\begin{tabular}{|c|} 
Post-test \\
3.97
\end{tabular}} \\
\hline 1 & I listen to the lecturer's instruction attentively. & & \\
\hline 2 & In the discussion of new topics, I take an active part and raise my points. & 2.97 & 3.22 \\
\hline 3 & I really make an effort in the mathematics lesson. & 4.16 & 4.08 \\
\hline 4 & I concentrate very hard when the teacher introduces new mathematical concepts. & 4.05 & 4.05 \\
\hline 5 & I will use every means to understand what the lecturer teaches in mathematics. & 4.30 & 3.89 \\
\hline 6 & I always take part in the discussion in the mathematics class. & 3.32 & 3.46 \\
\hline
\end{tabular}

As shown in Table 16, the mean values of the attentiveness aspect of students' behavioural engagement was 3.79 in the pre-test and 3.78 in the post-test; these values are almost same. Before the use of the ACE teaching cycle the level of students' attentiveness in learning mathematics was high and after the use of the approach their attentiveness level was still high. So, the researcher could deduce that the use of the approach maintained the students' high level of attentiveness. Further details about the students' response to all of the items can be seen in Table 17.

Table 17 shows a significant increase in the mean values for item 2, "In the discussion of new topics, I take an active part and raise my points", and for item 6, "I always take part in the discussion in the mathematics class." The students' responses to these two items suggest that the use of the approach has had the effect of improving their attentiveness in learning especially in relation to discussion activities. The improvement in these items was possible because the ACE teaching cycle approach enabled them to be actively involved in discussion activities.

There was significant decrease in the mean value for item 5 , "I will use every means to understand what the lecturer teaches in mathematics." The mean value of this item decreased from 4.30 in the pre-test to 3.89 in the post-test. The decrease in this mean value was not unexpected because the lecturer did not spend much time in explaining the materials in the ACE teaching cycle approach. Students did not depend on the lecturer to receive explanations about the topics.

A decrease in the mean value was also observed in item 3, "I really make an effort in the mathematics lesson." The mean value of this item decreased slightly from 4.16 in the pre-test to 4.08 in the post-test. These mean values were slightly above 4 , suggesting that most of the students gave their responses as option 4 (often) or as option 5 (almost always). So, most of the students really made an effort in learning mathematics not only in learning with the ACE teaching cycle but also in the learning before the implementation of the ACE teaching cycle.

\section{Diligence aspect of students' behavioural engagement}

The purpose of analysing the data in this section was to evaluate the effects of the use of the ACE teaching cycle in the Elementary Linear Algebra course on the diligence aspect of students' behavioural engagement. As a lecturer and researcher in this study, my expectation was that the use of this approach in my teaching practice would have a positive effect on the students' diligence in mathematics learning. The data for this approach came from focus group interviews and the questionnaire.

In focus group interview Zola revealed that "To produce a concept map I have to study hard; I read the material several times until I really understood the concept." This comment showed Zola's persistence 
Table 18. Descriptive statistics for diligence subscale of the SEMC in the pre-test and post-test $(\mathrm{n}=37)$

\begin{tabular}{lcccc}
\hline \multirow{2}{*}{ No. of items } & \multicolumn{2}{c}{ Pre-test } & \multicolumn{2}{c}{ Post-test } \\
\cline { 2 - 5 } & Mean & Standard deviation & Mean & Standard deviation \\
\hline 6 & 3.79 & 0.84 & 3.94 & 0.75 \\
\hline
\end{tabular}

in learning. He had the willpower to understand the topics. He realized that if he didn't understand the topics then he would face difficulty in developing the concept maps.

Budi also gave his response which related to diligence:

This approach encourages me to study hard. In the conventional classroom there are no concept maps, and there are no reflective journals. It only had exercises. I had allocated more time to learn with this approach.

Budi revealed that the use of ACE teaching cycle in the Elementary Linear Algebra had influenced his way of learning. He became more diligent and allocated more time to study.

The persistence in learning was also revealed by Yanti:

When I drew a concept map I had to understand the topics first. So, I pushed myself to understand the topics before drawing the concept map. In other subjects that were taught in the conventional way, if I found difficulty to solve a problem or to understand a concept I didn't care and I would not study hard for it, because I knew the lecturer would give the complete explanation in the classroom.

Yanti also stated that the teaching approach had encouraged her to study hard so that she was able to understand the materials and complete her tasks. She also indicated her reaction in facing difficulties in other subjects that were taught conventionally; she just waited for the lecturer to explain the issues that were difficult to understand.

Febrina also revealed her diligence in learning by saying, "In learning I am not only used to the main textbook but also I used other books and internet facility to support my learning. I did that if I need more explanations". Her diligence in learning showed that Febi had engagement in learning mathematics. She was encouraged to better understanding of the topics deeper through learning from various sources.

The data about this diligence aspect also came from the questionnaire. Students were required to provide their responses to six items of the diligence aspect of students' behavioural engagement. The questionnaire was administered to students on two occasions, before and after the use of ACE teaching cycle. Table 18 shows the mean values and standard deviation of students' responses to all items of the diligence aspect of students' behavioural engagement.

Table 18 shows that the mean value of students' response on the diligence aspect of behavioural engagement improved from 3.79 in the pre-test to 3.94 in the post-test. This increase suggests that the use of the ACE teaching cycle had affected students' diligence in mathematics learning. This was possible because the approach had facilitated them to be involved in learning through various activities. Table 19 presents the mean values of the students' responses on to each item of the diligence aspect. 
Table 19. Mean of the students' responses to each item of the diligence subscale of the SEMC in the pretest and the post-test $(n=37)$

\begin{tabular}{|c|c|c|c|}
\hline \multirow{2}{*}{\multicolumn{2}{|c|}{ No Items }} & \multicolumn{2}{|c|}{ Mean } \\
\hline & & \multirow{2}{*}{$\begin{array}{c}\text { Pre-test } \\
3.95\end{array}$} & \multirow{2}{*}{$\begin{array}{c}\text { Post-test } \\
3.92\end{array}$} \\
\hline 1 & For difficult problem, I would study hard until I understand them. & & \\
\hline 2 & If I cannot arrive at the right answer straight away. I will try again later. & 3.70 & 3.86 \\
\hline 3 & If I cannot tackle a problem, I would try again later. & 3.59 & 3.78 \\
\hline 4 & If I make mistake in solving problems, I will work until I have corrected them. & 3.84 & 4.00 \\
\hline 5 & If I work on problems persistently, I am sure that I will get the right answer. & 4.19 & 4.24 \\
\hline 6 & If I cannot solve a problem right away, I will persist in trying different methods until I get the solution. & 3.49 & 3.81 \\
\hline
\end{tabular}

In Table 19, an increase in the mean value occurred for almost all items, except for item 1 where there was a slight decrease. The increasing mean values for the other five items was an indication that students tended to be more diligently in their learning as a result of the implementation of the ACE teaching cycle. This improvement was possible because the ACE teaching cycle approach provided opportunities to students to be actively involved in the teaching and learning process. So, the use of the approach has had the same influence on the diligence aspect of behavioural engagement that expected by the researcher.

The use of the ACE teaching cycle approach in the Elementary Linear Algebra course at Padang State University for one semester has influenced the students' engagement in learning. The influences could be seen from the qualitative and quantitative data in the three domains of students' engagement in learning namely, cognitive, affective, and behavioural.

The qualitative data revealed the effects of the use of the ACE teaching cycle approach on the three domains of cognitive engagement. On cognitive engagement, students displayed their engagement through three aspects namely, surface strategy, deep strategy, and reliance. The data revealed that the students used both surface strategy and deep strategy in their efforts to engage in the teaching and learning process. The qualitative data also revealed that students became more independent in their learning and their dependence to acquire knowledge from the lecturer decreased. On affective engagement, students demonstrated their engagement through four aspects namely, interest, achievement orientation, anxiety, and frustration. The qualitative data revealed that the use of the ACE teaching cycle approach has had impact on students' engagement in learning in the following aspects: the students were more interested in learning; students were encouraged to study hard to achieve their goals; students felt happy and safe in learning; and the level of students' frustration tended to diminish. On behavioural engagement, students demonstrated their engagement through two aspects namely, attentiveness and diligence. The data about these aspects revealed that the use of the approach had impact on students' engagement with students demonstrating their active involvement in the teaching and learning process and in their diligence in learning.

The quantitative data that were obtained from the Student Engagement in the Mathematics Classroom questionnaire also showed the effects of the use of the ACE teaching cycle approach in the Elementary Linear Algebra course. Students gave their responses to the questionnaire on two occasions, before and after the use of the approach in their learning process. Table 20 presents the mean values of all aspects of engagement in the pre-test and the post-test. 
Table 20. Mean values and standard deviations of the aspects of engagement of the SEMC in the pretest and post-test $(n=37)$

\begin{tabular}{lcccc}
\hline \multirow{2}{*}{ Aspects of Engagement } & \multicolumn{3}{c}{ Pre-test } & \multicolumn{2}{c}{ Post-test } \\
\cline { 2 - 5 } & Mean & Standard deviation & Mean & Standard deviation \\
\hline Cognitive Engagement & & & & 0.89 \\
Surface Strategy & 2.98 & 1.02 & 2.92 & 0.78 \\
Deep Strategy & 3.39 & 0.88 & 3.50 & 0.68 \\
$\quad$ Reliance & 3.70 & 0.67 & 3.78 & 0.69 \\
\hline Affective Engagement & & & 4.17 & 0.59 \\
$\quad$ Interest & 4.02 & 0.76 & 4.50 & 0.85 \\
Achievement Orientation & 4.54 & 0.63 & 3.46 & 0.74 \\
$\quad$ Anxiety & 3.49 & 0.86 & 1.66 & 0.81 \\
$\quad$ Frustration & 1.75 & 0.76 & & 3.78 \\
\hline Attentiveness & & & 3.94 & 0.75 \\
Diligence & 3.79 & 0.83 & & \\
\hline
\end{tabular}

The researcher had expected that the mean values of seven aspects (surface strategy, deep strategy, reliance, interest, achievement orientation, attentiveness, and diligence) of the total of nine aspects of engagement to increase. An increase in the mean values occurred for most of the aspects of engagement except for achievement orientation and attentiveness. However, the mean values of these two aspects were slightly decreased although their mean values were high before and after the use of the approach. On the aspects of anxiety and frustration, the mean value of the two aspects was seen to decrease. This result is similar to what the researcher had expected. So, based on this quantitative data, the researcher can say that the use of the ACE teaching cycle approach in the Elementary Linear Algebra course has had an effect on students' engagement in learning, with students becoming more engaged in their learning.

So, based on the qualitative and quantitative data the researcher can say that the implementation of the ACE teaching cycle approach in the Elementary Linear Algebra course has had an effect on students' engagement in learning, as the approach has encouraged students to improve their engagement in learning elementary linear algebra.

Author contributions: All authors were involved in concept, design, collection of data, interpretation, writing, and critically revising the article. All authors approve final version of the article.

Funding: The authors received no financial support for the research and/or authorship of this article.

Declaration of interest: Authors declare no competing interest.

Data availability: Data generated or analysed during this study are available from the authors on request.

\section{REFERENCES}

Açıkgül, K., \& Şad, S. N. (2020). Mobile technology acceptance scale for learning mathematics: Development, validity, and reliability studies. International Review of Research in Open and Distributed Learning, 21(4), 161-180. https://doi.org/10.19173/irrodl.v21i4.4834

Açıkgül, K., \& Şad, S. N. (2021). High school students' acceptance and use of mobile technology in learning mathematics. Education and Information Technologies, 26, 4181-4201. https://doi.org/10.1007/s10639-021-10466-7

Agustini, N. W. W. (2019). English teacher' perceptions and classroom practices on constructivism values in primary schools in Badung Regency. Jurnal Pendidikan Bahasa Inggris Indonesia, 7(2), 1-11. https://doi.org/10.23887/jpbi.v7i2.2722

Akilli, M., \& Genç, M. (2017). Modelling the effects of selected affective factors on learning strategies and classroom activities in science education. Journal of Baltic Science Education, 16(4), 599. https://doi.org/10.33225/jbse/17.16.599

Al Ansari, M., Al Bshabshe, A., Al Otair, H., Layqah, L., Al-Roqi, A., Masuadi, E., Alkharashi, N., \& Baharoon, S. (2021). Knowledge and confidence of final-year medical students regarding critical care core-concepts, a comparison between problem-based learning and a traditional curriculum. Journal of Medical Education and Curricular Development, 8, 2382120521999669. https://doi.org/10.1177/2382120521999669

Aldon, G., \& Tragalová, J. (2019). Technology in mathematics teaching. Springer International Publishing. https://doi.org/10.1007/9783-030-19741-4

Anderson, G. (2002). Fundamental of educational research (2nd ed.). Routledge Falmer. 
Anton, H. (2004). Aljabar linear elementer. Erlangga.

Archambault, I., Janosz, M., Morizot, J., \& Pagani, L. (2009). Adolescent behavioral, affective, and cognitive engagement in school; Relationship to dropout. Journal of School Health, 79(9), 408-415. https://doi.org/10.1111/j.1746-1561.2009.00428.x

Arnawa, I. M. (2006). Meningkatkan kemampuan pembuktian mahasiswa dalam aljabar abstrak melalui pembelajaran berdasarkan teori APOS [Improve students' proofing skills in abstract algebra through learning based on APOS theory]. (S3), UPI, Bandung.

Asiala, M., Cottrill, J., Dubinsky, E., \& Schwingendorf, K. E. (1997). The development of students' graphical understanding of the derivative. The Journal of Mathematical Behavior, 16(4), 399-431. https://doi.org/10.1016/s0732-3123(97)90015-8

Asiala, M., Dubinsky, E., Mathews, D. M., Morics, S., \& Oktaç, A. (1997). Development of students' understanding of cosets, normality, and quotient groups. The Journal of Mathematical Behavior, 16(3), 241-309. https://doi.org/10.1016/s07323123(97)90029-8

Askew, M., Bowie, L., \& Venkat, H. (2019). Pre-service primary teachers' mathematical content knowledge: An exploratory study. African Journal of Research in Mathematics, Science and Technology Education, 23(3), 286-297. https://doi.org/10.1080/18117295.2019.1682777

Attard, C. (2011). The influence of teachers on student engagement with mathematics during the middle years. http://www.merga.net.au/documents/RP_ATTARD_MERGA34-AAMT.pdf

Atweh, B. (2004). Understanding for changing and changing for understanding. In P. V. a. R. Zevenbergen (Ed.), Researching the socio-political dimensions of mathematics education: Issues of power in theory and methodology (pp. 1-19). Kluwer Academic. https://doi.org/10.1007/1-4020-7914-1_16

Baek, J. (2019). EFL college students' learning experiences during film-based reading class: Focused on the analysis of students' reflective journals. International Journal of Advanced Culture Technology, 7(4), 49-55.

Biggs, J. B. (1978). Individual and group differences in study processes. British Journal of Education Psychology, 48, 266-279. https://doi.org/10.1111/j.2044-8279.1978.tb03013.x

Bodner, G. M. (1986). Constructivism: A theory of knowledge. Journal of Chemical Education, 63(10), 873-878. https://doi.org/10.1021/ed063p873

Bodner, G., \& Elmas, R. (2020). The impact of inquiry-based, group-work approaches to instruction on both students and their peer leaders. European Journal of Science and Mathematics Education, 8(1), 51-66. https://doi.org/10.30935/scimath/9546

Borji, V., \& Voskoglou, M. G. (2017). Designing an ACE Approach for teaching the polar coordinates. American Journal of Educational Research, 5(3), 303-309.

Brijlall, D., \& Maharaj, A. (2009). Applying APOS theory as a theoretical framework for collaborative learning in teacher education. http://tsg.icme11.org/document/get/857

Cano, J. M. M., Salazar, T. D. N. J. M., Priego, C. G., \& Hernández, J. A. C. (2018). Construction of media competence in medical education through flipped classroom in a traditional curriculum. Transylvanian Review, 26(28).

Carini, R., Kuh, G., \& Klein, S. (2006). Student engagement and student learning: Testing the linkages. Research in Higher Education, 47(1), 1-32. https://doi.org/10.1007/s11162-005-8150-9

Casinillo, L., Camulte, M. C., Raagas, D., \& Riña, T. S. (2020). Cultural factors in learning mathematics: the case on achievement level among Badjao students. International Journal of Indonesian Education and Teaching, 4(1), 71-81.

Cattaneo, L. B., Shor, R., Calton, J. M., Gebhard, K. T., Buchwach, S. Y., Elshabassi, N., \& Hargrove, S. (2019). Social problems are social: Empirical evidence and reflections on integrating community psychology into traditional curriculum. Global Journal of Community Psychology Practice, 10(1), 1-29.

Caulfield, J. (2010). Applying graduate student perceptions of task engagement to enhance learning conditions. International Journal for the Scholarship of Teaching and Learning, 4(1), 8. https://doi.org/10.20429/ijsotl.2010.040108

Chan, K. K. H., \& Hume, A. (2019). Towards a consenus model: Literature review of how science teachers' pedagogical content knowledge is investigated. In A. Hume, R. Cooper, \& A. Borowski (Eds.), Repositioning PCK in teachers' professional knowledge (pp. 3-76). Springer. https://doi.org/10.1007/978-981-13-5898-2_1

Chapman, E. (2003). Alternative approaches to assessing student engagement rates. Practical Assessment, Research \& Evaluation, 8, 13.

Charalambous, C. Y., Hill, H. C., Chin, M. J., \& McGinn, D. (2020). Mathematical content knowledge and knowledge for teaching: exploring their distinguishability and contribution to student learning. Journal of Mathematics Teacher Education, 23(6), 579613. https://doi.org/10.1007/s10857-019-09443-2

Cho, H. J., Wang, C., Bonem, E. M., \& Levesque-Bristol, C. (2021). How can we support students' learning experiences in higher education? Campus wide course transformation program systematic review and meta-analysis. Innovative Higher Education, 1-30. https://doi.org/10.1007/s10755-021-09571-9

Cole, M. (1996). Cultural psychology: A once and future discipline. Harvard University Press.

Copley, J. (1992). The integration of teacher education and technology: A constructivist model. AACE. 
Copur-Gencturk, Y., Jacobson, E., \& Rasiej, R. (2021). On the alignment of teachers' mathematical content knowledge assessments with the common core state standards. Journal of Mathematics Teacher Education, 1-25. https://doi.org/10.1007/s10857-02109486-4

Creswell, J. W. (2008). Educational research: planning, conducting, and evaluating quantitative and qualitative research (3th ed.). Pearson Merrill Prentice Hall.

Creswell, J. W., \& Plano Clark, V. L. (2010). Chapter 1: The nature of mixed methods research. In Designing and conducting mixed methods research (pp. 1-18). www.sagepub.com/upm-data/35003_Chapter1.pdf

Crowder, C. D. (2011). How to overcome mathematics test anxiety. http://www.brighthubeducation.com/test-taking-tips/101369overcoming-math-anxiety/

Daniel, L. (2017). The interplay between pre-service teachers' intentions and enacted mathematical content knowledge in the classroom. Mathematics Education Research Group of Australasia.

De Oliveira, D. F. M., Simas, B. C., Guimarães Caldeira, A. L., Medeiros, A. D. G. E. B., Freitas, M. R., Jr, J. D., \& Diniz, R. (2018). School of Medicine of Federal University of Rio Grande Do Norte: A traditional curriculum with innovative trends in medical education. Medical teacher, 40(5), 467-471. https://doi.org/10.1080/0142159X.2018.1440080

Denton, J. M., Esparza, S. D., Fike, D. S., \& González, J. (2018). Improvements in cultural competence in athletic training and rehabilitative science students through classroom activities. Journal of Cultural Diversity, 25(1), 32-37.

Dikici, A. (2006). The effects of cooperative learning on the abilities of pre-service art teacher candidates to lesson planning in Turkey. Australian Journal of Teacher Education, 31(2), 35-44. https://doi.org/10.14221/ajte.2006v31n2.4

Dinh, H. (2019). Towards a knowledge-rich curriculum. Journal of Curriculum Studies Research, 1(1), 54-70. https://doi.org/10.46303/jcsr.01.01.5

D'mello, K. (2008). How can we maximise student engagement in the classroom?

Driscoll, M P. (2000). Psychology of learning for instruction (2nd ed.). Allyn and Bacon.

Dubinsky, E. (1995). ISETL: a programming language for learning mathematics. Communications on Pure and Applied Mathematics, XLVIII, 1027-1051. https://doi.org/10.1002/cpa.3160480905

Dubinsky, E. (2001). Using a theory of learning in college mathematics course. https://doi.org/10.11120/msor.2001.01020010

Elmore, R. F. (1990). Restructuring school: The next generation of educational reform. Jossey-Bass.

Exley, B. (2008). Communities of learners: Early years students, new learning pedagogies, and transformations. In A. Healy (Ed.), Multiliteratures and diversity in education: new pedagogies for expanding landscape (pp. 126-143). University Press.

Finn, J. D. (1993). School engagement and students at risk. National Center for Education Statistics.

Fosnot, C. T. (1996). Constructivism: Theory, perspective, and practice. Teachers College Press.

Fredricks, J. A., Blumenfeld, P. C., \& Paris, A. H. (2004). School engagement: Potential of the concept, state of the evidence. Review of Educational Research, 74(1), 59-110. https://doi.org/10.3102/00346543074001059

Fuentes-Cabrera, A., Parra-González, M. E., López-Belmonte, J., \& Segura-Robles, A. (2020). Learning mathematics with emerging methodologies-The escape room as a case study. Mathematics, 8(9), 1586. https://doi.org/10.3390/math8091586

Ganapathy, M., Kaur, M., \& Kaur, S. (2017). Tertiary students' learning practices using information and communication technology to promote higher-order thinking. Pertanika Journal of Social Sciences \& Humanities, 25(2), 877-890.

Getenet, S., \& Callingham, R. (2021). Teaching interrelated concepts of fraction for understanding and teacher's pedagogical content knowledge. Mathematics Education Research Journal, 33, 201-221. https://doi.org/10.1007/s13394-019-00275-0

Hava, K., Guyer, T., \& Cakir, H. (2020). Gifted students' learning experiences in systematic game development process in afterschool activities. Educational Technology Research and Development, 68(3), 1439-1459. https://doi.org/10.1007/s11423-02009750-z

Janna, I., Christopher, K., Barbara, S., Kalle, J., Joseph, K., Jari, L., \& Katariina, S. A. (2019). Science classroom activities and student situational engagement. International Journal of Science Education, 41(3), 316-329. https://doi.org/10.1080/09500693.2018.1549372

Jitka, N., Jitka, P., \& Pavlna, K. (2018). Teacher's concept of constructivism in real conditions of school teaching. Journal of Education and Training Studies, 6(n11a), 133-138. https://doi.org/10.11114/jets.v6i11a.3810

Kemmis, S., \& McTaggart, R. (1988). The action research planner. Deakin University.

Kent, L. (2017). Examining mathematics classroom interactions: Elevating student roles in teaching and learning. International Journal of Educational Methodology, 3(2), 93-102. https://doi.org/10.12973/ijem.3.2.93

Kent, M, Gilbertson, D, \& Hunt, C. (1997). Fieldwork in geography teaching: A critical review of the literature and approaches. Journal of Geography in Higher Education, 21(3), 313-332. https://doi.org/10.1080/03098269708725439

Kind, V., \& Chan, K. K. (2019). Resolving the amalgam: connecting pedagogical content knowledge, content knowledge and pedagogical knowledge. International Journal of Science Education, 41(7), 964-978. https://doi.org/10.1080/09500693.2019.1584931

King, E. (2020). Implications for the child friendly schools policy within Cambodia's cultural and primary school context. AsiaPacific Journal of Teacher Education, 48(4), 375-388. https://doi.org/10.1080/1359866X.2019.1645811 
Kong, Q. P., Wong, N. Y., \& Lam, C. C. (2003). Student engagement in mathematics: development of instrument and validation of construct. Mathematics Education Research Journal, 15(1), 4-21. https://doi.org/10.1007/BF03217366

LaMotte, M. (2018). The integrated approach versus the traditional approach: Analyzing the benefits of a dance and transportation integrated curriculum. Journal of Dance Education, 18(1), 23-32. https://doi.org/10.1080/15290824.2017.1336667

Livy, S., \& Vale, C. (2011). First year pre-service teachers' mathematical content knowledge: methods of solution for a ratio question. Mathematics Teacher Education and Development, 13(2), 22-43.

Livy, S., Herbert, S., \& Vale, C. (2019). Developing primary pre-service teachers' mathematical content knowledge: Opportunities and influences. Mathematics Education Research Journal, 31(3), 279-299. https://doi.org/10.1007/s13394-018-0252-8

Lo, W. Y. (2020). Examining the mathematical content knowledge of pre-service primary teachers at the highest primary school level in Hong Kong. Teacher Development, 24(3), 315-332. https://doi.org/10.1080/13664530.2020.1758760

Ma, L. (1999). Knowing and teaching elementary mathematics; teachers' understanding of fundamental mathematics in China and the United States. Lawrence Erlbaum Associates, Inc. https://doi.org/10.4324/9781410602589

Maharaj, A. (2011). An APOS analysis of students' understanding of the concept of a limit of a function. Pythagoras: Journal of the Association for Mathematics Education of South Africa, 71(2010), 41-52. https://doi.org/10.4102/pythagoras.v0i71.6

Mainali, B. (2021). Representation in teaching and learning mathematics. International Journal of Education in Mathematics, Science and Technology, 9(1), 1-21. https://doi.org/10.46328/ijemst.1111

Marks, H. M. (2000). Students engagement in instructional activity: Patterns in the elementary, middle, and high school years. American Educational Research Journal, 37(1), 153-184. https://doi.org/10.3102/00028312037001153

Masaviru, M. (2020). From physical classrooms to e-learning and online teaching: A case study of Light International School, Mombasa. Journal of Education and Practice, 11(13), 57-72. https://doi.org/10.31219/osf.io/6x2zb

Mathison, S. (1988). Why triangulate? Educational Researcher, 17(2), 13-17. https://doi.org/10.3102/0013189X017002013

Mazana, Y. M., Suero Montero, C., \& Olifage, C. R. (2019). Investigating students' attitude towards learning mathematics. International Electronic Journal of Mathematics Education, 14(1), 207-231. https://doi.org/10.29333/iejme/3997

McMillan, J. H. (1992). Educational research: Fundamental for consumers. Harper Collins Publishers Inc.

Mills, G. E. (2007). Action research: a guide for the teacher researcher (4th ed.). Pearson Education, Inc.

Miserandino, M. (1996). Children who do well in school: Individual differences in perceived competenceand autonomy in aboveaverage children. Journal of Educational Psychology, 88(2), 203-214. https://doi.org/10.1037/0022-0663.88.2.203

Mulenga, E. M., \& Marbán, J. M. (2020). Prospective teachers' online learning mathematics activities in the age of COVID-19: A cluster analysis approach. EURASIA Journal of Mathematics, Science and Technology Education, 16(9), em1872. https://doi.org/10.29333/ejmste/8345

NCTM. (2000). Principles and standards for school mathematics. www.nctm.org

Nesmith, S. J. (2008). Mathematics and literature: Educators' perspectives on utilizing a reformative approach to bridge two cultures. http://forumonpublicpolicy.com/summer08papers/archivesummer08/nesmith.pdf

Neumann, K., Kind, V., \& Harms, U. (2019). Probing the amalgam: the relationship between science teachers' content, pedagogical and pedagogical content knowledge. International Journal of Science Education, 41(7), 847-861. https://doi.org/10.1080/09500693.2018.1497217

Newmann, F. M. (1992). Student engagement and achievement in American secondary school. Teachers Collage Press.

Newmann, Fred M., \& Lamborn, S. D. (1992). The significance and source of student engagement. In F. M. Newmann (Ed.), Student engagement and achievement in American secondary school (pp. 11-39). Teachers College Press.

Nguyen, T. T. T., Seki, N., \& Morio, I. (2018). Stress predictors in two Asian dental schools with an integrated curriculum and traditional curriculum. European Journal of Dental Education, 22(3), e594-e601. https://doi.org/10.1111/eje.12358

Norton, S. (2019). The relationship between mathematical content knowledge and mathematical pedagogical content knowledge of prospective primary teachers. Journal of Mathematics Teacher Education, 22(5), 489-514. https://doi.org/10.1007/s10857018-9401-y

O'Toole, J., \& Beckett, D. (2010). Educational research: creating thinking \& doing. Oxford University Press.

Özgür, H. (2020). Relationships between teachers' technostress, technological pedagogical content knowledge (TPACK), school support and demographic variables: A structural equation modeling. Computers in Human Behavior, 112, 106468. https://doi.org/10.1016/j.chb.2020.106468

Pazicni, S., \& Flynn, A. B. (2019). Systems thinking in chemistry education: Theoretical challenges and opportunities. Journal of Chemical Education, 96(12), 2752-2763. https://doi.org/10.1021/acs.jchemed.9b00416

Pedro, J., \& Brunheira, L. (2001). Analysing practice in preservice mathematics teacher education. Mathematics Education Research Journal, 3(1), 16-27.

Peker, E., \& Ataöv, A. (2020). Exploring the ways in which campus open space design influences students' learning experiences. Landscape Research, 45(3), 310-326. https://doi.org/10.1080/01426397.2019.1622661

Peker, M. (2009). Pre-service teachers' teaching anxiety about mathematics and their learning styles. Eurasia Journal of Mathematics, Science \& Technology Education, 5(4), 335-345. https://doi.org/10.12973/ejmste/75284 
Pierce, R., Kaye, S., \& Anastasios, B. (2005). A scale for monitoring students' attitude to learning mathematics with technology. Computer \& Education, 48(2007), 285-300. https://doi.org/10.1016/j.compedu.2005.01.006

Potgieter, E. (2020). Pedagogies of play to develop intermediate phase mathematics teachers' metacognitive awareness (Doctoral dissertation, North-West University). https://doi.org/10.20472/IAC.2019.051.033

Rohaizati, U. (2020, February). Junior secondary school teachers and students' needs for the use of digital comics in learning mathematics. In Journal of Physics: Conference Series (Vol. 1460, No. 1, p. 012026). IOP Publishing. https://doi.org/10.1088/1742-6596/1460/1/012026

Rotgans, J. I., \& Schmidt, H. G. (2011). Cognitive engagement in the problem-based learning classroom. Advance in Health Science Education, 16(4), 465-479. https://doi.org/10.1007/s10459-011-9272-9

Sacristán, A. I. (2019, July). Mathematics teachers' education for technological integration: Necessary knowledge and possible online means for its development. Introduction to the Section. In Technology in Mathematics Teaching: Selected Papers of the 13th ICTMT Conference (Vol. 13, p. 173). Springer.

Salame, I. I., Casino, P., \& Hodges, N. (2020). Examining Challenges that Students Face in Learning Organic Chemistry Synthesis. International Journal of Chemistry Education Research, 4(1), 1-9. https://doi.org/10.20885/ijcer.vol4.iss1.art1

Sarantakos, S. (2005). Social research. Palgrave Macmillan. https://doi.org/10.1007/978-0-230-20901-5

Schifter, D., \& Simon, M. A. (1992). Assessing teachers' development of a constructivist view of mathematics learning. Teaching and Teacher Education, 8(2), 187-197. https://doi.org/10.1016/0742-051X(92)90008-Q

Schmid, M., Brianza, E., \& Petko, D. (2020). Developing a short assessment instrument for Technological Pedagogical Content Knowledge (TPACK. xs) and comparing the factor structure of an integrative and a transformative model. Computers $\mathcal{E}$ Education, 157, 103967. https://doi.org/10.1016/j.compedu.2020.103967

Schulman, L S. (1998). Teaching and teacher education among profession. Elementary School Journal, 98(5), 511-526. https://doi.org/10.1086/461912

Scott, T., \& Husain, F. N. (2021). Textbook Reliance: Traditional Curriculum Dependence Is Symptomatic of a Larger Educational Problem. Journal of Educational Issues, 7(1), 233-248. https://doi.org/10.5296/jei.v7i1.18447

Selvanathan, M., Hussin, N. A. M., \& Azazi, N. A. N. (2020). Students learning experiences during COVID-19: Work from home period in Malaysian higher learning institutions. Teaching Public Administration, 0144739420977900. https://doi.org/10.1177/0144739420977900

Setianingsih, R., Sa'dijah, C., As'ari, A. R., \& Muksar, M. (2017). Investigating fifth-grade students' construction of mathematical knowledge through classroom discussion. International Electronic Journal of Mathematics Education, 12(3), 383-396.

Shrivastava, S. R., \& Shrivastava, P. S. (2020). Advocating for the retention of positive attributes of the traditional curriculum amidst the transition to the competency based curriculum in medical education delivery. South-East Asian Journal of Medical Education, 13(2), 14. https://doi.org/10.4038/seajme.v13i2.205

Skinner, E., \& Belmont, M. (1993). Motivation in the classroom: Reciprocal effect of teacher behaviour and student engagement across the school year. Journal of Educational Psychology, 85(4), 571-581. https://doi.org/10.1037/0022-0663.85.4.571

Sulistyowati, T. (2019). Bottom-up and top-down listening processes within cognitive constructivist learning theory. PROMINENT Journal, 2(1), 92-100. https://doi.org/10.24176/pro.v2i1.2962

Tabach, M., \& Trgalová, J. (2018). ICT standards for teachers: Toward a frame defining mathematics teachers' digital knowledge. In H.-G. Weigand, et al. (Eds.), Proceedings of the 5th ERME Topic Conference. Mathematics Education in the Digital Age (pp. 273-280). University of Copenhagen.

Tabach, M., \& Trgalová, J. (2019). The knowledge and skills that mathematics teachers need for ICT integration: The issue of Standards. In Technology in mathematics teaching (pp. 183-203). Springer. https://doi.org/10.1007/978-3-030-19741-4_8

Tabach, M., \& Trgalová, J. (2020). Teaching mathematics in the digital era: Standards and beyond. In STEM Teachers and Teaching in the Digital Era: Professional Expectations and Advancement in the 21st Century Schools (pp. 221-242). Springer. https://doi.org/10.1007/978-3-030-29396-3_12

Tanak, A. (2020). Designing TPACK-based course for preparing student teachers to teach science with technological pedagogical content knowledge. Kasetsart Journal of Social Sciences, 41(1), 53-59.

Taplin, M. (1998). Preservice teachers' problem-solving processes. Mathematics Education Research Journal, 10(3), 59-76. https://doi.org/10.1007/BF03217058

Technology Assistance Program. (1998). Constructivism and technology on the road to student-centered learning. TAP into Learning, 1(1).

Tomlinson, A. (2002). Invitation to learn. Educational Leadership, 60(1), 6-10.

Trigueros, M., Oktac, A., \& Manzanero, L. (2007). Understanding of system of equation in linear algebra. http://ermeweb.free.fr/CERME\%205/WG14/14_Trigueros.pdf

Tsybulsky, D. (2020). Digital curation for promoting personalized learning: A study of secondary-school science students' learning experiences. Journal of Research on Technology in Education, 52(3), 429-440. https://doi.org/10.1080/15391523.2020.1728447

Werner, J. M., Scovotti, C., Cummings, R. G., \& Bronson, J. W. (2018). Building a case for active learning: The use of lecture vs. other classroom activities at LMBC. Journal of Learning in Higher Education, 14(1), 7-15. 
Zahner, W., Calleros, E. D., \& Pelaez, K. (2021). Designing learning environments to promote academic literacy in mathematics in multilingual secondary mathematics classrooms. ZDM Mathematics Education, 53, 359-373. https://doi.org/10.1007/s11858021-01239-0 